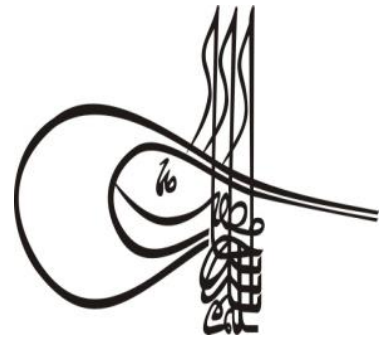

Received/Geliş: 21.06.2019

\section{Turkigh Studies Educational Sciences}

Volume 14 Issue 4, 2019, p. 1941-1970

DOI: 10.29228/TurkishStudies.23449

ISSN: 2667-5609

Skopje/MACEDONIA-Ankara/TURKEY

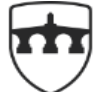

INTERNATIONAL BALKAN UNIVERSITY

EXCELLENCE FOR THE FUTUR IBU.EDU.MK

Research Article / Araştırma Makalesi

Article Info/Makale Bilgisi

$\checkmark$ Accepted/Kabul: 10.08.2019

Gor Report Dates/Rapor Tarihleri: Referee 1 (22.07.2019)-Referee 2 (23.07.2019)

This article was checked by iThenticate.

\title{
İŞBİRLİĞİNE DAYALI ÖĞRENME YÖNTEMİ: TÜM TEKNIKLLERI KAPSAYICI BİR DERLEME ÇALIŞMASI
}

\author{
Etem YEŞILYURT*
}

\begin{abstract}
öz
Eğitim sisteminin temel amacı, bireylerde istendik yönde davranış değişikliği oluşturmaktır. Bu değişikliklerin olmasında "öğrenme" kavramı kritik konumda yer almaktadır. Tarihsel süreçte insanın nasıl öğrendiği merak ve araştırma konusu olmusstur. Bu soruya öğretmeöğretme kuramları, yaklaşımları, modelleri, stilleri, ilkeleri, yöntemleri, teknikleri cevap vermek amaciyla kuram ve uygulamada yerini almıştır. İşbirliğine dayalı öğrenme yöntemi de bunlardan biridir. Yapılan literatür taraması sonucunda bazı kaynaklarda işbirliğine dayalı öğrenme yöntemi ile ilgili bir veya birkaç tekniğe ayrıntıll yer verildiğine, bazı kaynaklarda ise tekniklerin geneline yer verilmesine rağmen bunların birkaç cümleyle yüzeysel olarak açıklandığı görülmektedir. Ancak literatürde yer alan ve erissilen kaynaklarda işbirliğine dayalı öğrenme yöntemlerinin / tekniklerinin tamamının bir bütünlük içerisinde ve kapsamlı olarak açıklanmasına ulaşılamamıştır. Derleme niteliğinde olan bu çalışma, işbirliğine dayalı öğrenme yönteminin literatürde yer alan ve kabul gören tüm tekniklerini kapsayıcı ve ayrıntılı bir şekilde ele almak ve tüm tekniklere tek bir çalışma içerisinde ulaşmak amacıyla yapılmıștır. Çalışma kapsamında öncelikle Türkçe ve İngilizce literatürde işbirliğine dayalı öğrenme yönteminin kelime (kavramsal) kökeni ve kullanım şekilleri açıklanmıştır. Öte yandan bu yöntemin en temel öğesi olan işbirlikli veya yüksek işbirlikli öğrenme gruplarının diğer öğrenme gruplarından farklı özelliklerine yer verilmiștir. Ayrıca birden fazla öğrenenin bir araya gelerek oluşturdukları birlikteliğin veya grup çalışmasının işbirliğine dayalı öğrenme olabilmesi için sağlaması (taşımas1) gereken temel ilkeler ve bu ilkelerin genel özellikleri vurgulanmıştır. "Birlikte öğrenme", "işbirliği işbirliği", "takım-oyun-turnuva", "takım/küme destekli bireyselleştirme", "grup araştırması", "birlikte soralım birlikte
\end{abstract}


öğrenelim", "birleştirilmiş işbirlikli okuma ve kompozisyon", "öğrenci takımları-başarı bölümleri", "akademik çelişki/anlaşmazlık", "okumayazma-uygulama", "karş111klı soralım/sorgulama", "birleştirme (Jigsaw): birleştirme I-II-III-IV, ters birleştirme, konu birleştirme" olarak isimlendirilen işbirliğine dayalı öğrenme yönteminin teknikleri kapsamlı bir bütünlük içerisinde ele alınmış ve özellikleri açıklanmıştır. Çalışmada son olarak işbirliğine dayalı öğrenme yönteminin faydaları ile sınırlıklarına değinilmiştir.

Anahtar Kelimeler: İşbirliğine dayalı öğrenme, işbirlikli öğrenme, öğrenme-öğretim modelleri, öğrenme-öğretim yöntemleri, öğrenmeögretim teknikleri.

\title{
COOPERATIVE LEARNING METHOD: A COMPREHENSIVE LITERATURE REVIEW OF ALL TECHNIQUES
}

\begin{abstract}
The main purpose of education systems is to change individuals' behavior in the desired direction. "Learning" plays a key role in the development of desired behavioral changes. Therefore, how people learn has been the subject of curiosity and research in the historical process. Teaching-learning theories, approaches, models, styles, principles, methods and techniques have taken their place in theory and practice in order to answer this question. Cooperative learning is one of them. After reviewing the literature, it is seen that while one or several techniques of cooperative learning method are given in a detailed or very detailed way, some of the techniques are given in a general sense in some sources where the related explanation is given superficially with a few sentences. However, it has not been observed that all of the cooperative learning methods / techniques are explained in an integrated and comprehensive manner in the sources reached. This study is a review of all existing and accepted techniques in the literature, and it was conducted in order to reach all techniques in a single study.The word (conceptual) origin of cooperative learning method and its forms of use have been explained based on the literature in the first place within the scope of the study. Different features of cooperative or high cooperative learning groups, which are the most basic element of this method, from other learning groups are given in this study. Moreover, the basic principles and the general characteristics of the collaboration and group work to be a cooperative learning activity are emphasized. The techniques used in the cooperative learning method are: The techniques of Cooperative Learning methods named "Learning Together", "Co-op Co-op", "TeamsGames-Tournament", "Team Assisted Individualization", "Group Investigation", "Ask Together, Learn Together", "Cooperative Integrated Reading and Composition", "Student Teams Achievement Divisions", "Academic Controversy", "Reading-Writing-Application", "Mutual Inquiry, "Jigsaw: I, II, III, IV", "Reverse Jigsaw", and "Subject Jigsaw" are discussed in a comprehensive and unified manner. Finally, the benefits and limitations of the cooperative learning method are explained.
\end{abstract}




\section{STRUCTURED ABSTRACT}

The main purpose of education systems is to change individuals' behavior in the desired direction. "Learning" plays a key role in the development of desired behavioral changes. Therefore, how people learn has been the subject of curiosity and research in the historical process. Teaching-learning theories, approaches, models, styles, principles, methods and techniques have taken their place in theory and practice in order to answer this question. Cooperative learning is one of them.

After reviewing the literature, it is seen that while one or several techniques of cooperative learning method are given in a detailed or very detailed way, some of the techniques are given in a general sense in some sources where the related explanation is given superficially with a few sentences. However, it has not been observed that all of the cooperative learning methods / techniques are explained in an integrated and comprehensive manner in the sources reached. This study is a review of all existing and accepted techniques in the literature, and it was conducted in order to reach all techniques in a single study.

The word (conceptual) origin of cooperative learning method and its forms of use have been explained based on the literature in the first place within the scope of the study. Although cooperative learning is commonly used under the name operative Cooperative Learning, such names as "Work Group", "Collaborative Learning", "Collective Learning", "Learning Communities", "Team Learning", "Study Circles", "Study Group" and "Team Work" have been given to this concept in the relevant literature. In the most general terms, cooperative learning can be defined as a student-centered learning method that can be applied at every stage of education, where students work for a common purpose in heterogeneous groups on a subject, facilitate each other's learning, increase their self-esteem and self-esteem, develop communication, problem solving, critical thinking and social skills.

Different features of cooperative or high cooperative learning groups, which are the most basic element of this method, from other learning groups are given in this study. The differences between the cooperative and traditional learning groups are summarized in items. The main characteristics of cooperative and high cooperative learning groups can be explained as follows: The students in the cooperative learning group are directed to work together and are therefore very happy. At the same time, they realize that their success depends on the work of all group members. The commitment of the group members to each other is high in the high-performance cooperative learning group. There is a strong emotional bond between them. The success of the group is always higher than expected. It is reported that it has a rare group structure. Moreover, the basic principles and the general characteristics of the collaboration and group work to be a cooperative learning activity are emphasized. Such basic principles of cooperative learning as positive dependence (personal solidarity), individual (personal) responsibility, face-to-face (supportive) interaction, equal opportunity for success, interpersonal and group (social) skills, heterogeneous groups, group's self-assessment and its assessment of the process, rewards, post-group reflection, teacher role have been explained.

Turkish Studies - Educational Sciences

Volume 14 Issue 4, 2019 
There are many cooperative learning techniques. The application of these techniques depends on the basic principles of the cooperative learning method, but each has different features that stand out. These techniques are identical in essence. However, the way the techniques are applied differs depending on the variables such as the characteristics of the course, the level of education, the organization of the class, the formation of the groups, the operation stages of the cooperation process, and the assessment and evaluation. Different cooperative learning techniques are used effectively in different disciplines. The techniques used in the cooperative learning method are: The techniques of Cooperative Learning methods named "Learning Together", "Co-op Co-op", "Teams-Games-Tournament", "Team Assisted Individualization", "Group Investigation", "Ask Together, Learn Together", "Cooperative Integrated Reading and Composition", "Student Teams Achievement Divisions", "Academic Controversy", "ReadingWriting-Application", "Mutual Inquiry, "Jigsaw: I, II, III, IV", "Reverse Jigsaw", and "Subject Jigsaw" are discussed in a comprehensive and unified manner. In addition, the main differences between Jigsaw, Jigsaw II, Jigsaw III and Jigsaw IV techniques are emphasized. There are two main differences between Jigsaw-I and Jigsaw-II techniques. These differences are seen in creating positive dependence and rewarding group success. In Jigsaw-III technique, the application process is evaluated through standard forms unlike other techniques. The difference of Jigsaw-IV technique from other Jigsaw techniques is that the main points of the subject are explained by the teacher at the beginning of the lesson, the specialist groups are tested (quiz) before returning to their groups, and the missing parts are explained again by the teacher. Cooperative learning method is one of the rare methods that can be used in all teaching levels. It has been determined by scientific research results that this method is effective in acquiring the behaviors (aims, objectives, achievements) in cognitive, affective and psycho-motor domains which are three main areas of education. Finally, the benefits and limitations of the cooperative learning method are explained. However, the point that should be taken into consideration here is that the cooperative learning process, which is not well structured and the sense of duty and responsibility is not well established, has negative effects (limitations, disadvantages etc.). If this it is well structured, it can be seen that cooperative learning method is a useful and functional method in terms of cognitive, affective and psycho-motor aspects of all students in the group at any level regardless of their individual differences, and that it has almost no limitations.

Keywords: Cooperative learning, learning-teaching models, learning-teaching methods, learning-teaching techniques.

\section{Giriş}

Tekrar ya da yaşantı yoluyla organizmanın davranışlarında oluşan kalıcı izli değişiklikler öğrenme olarak tanımlanmaktadır. İnsan nasıl öğrenir; nitelikli, etkili ve kalıcı öğrenme nasıl olur; öğrenme için hangi yol ve yöntemler kullanılmalıdır; öğrenmede bireysel farklar var mıdır vb. birçok sorunun cevabı geçmişten günümüze kadar merak ve araştırma konusu olmuş ve konuyla ilgili birçok 
araştırma yapılmıştır. Yukarıda belirtilen sorulara cevap niteliğinde olan ve literatürde yerini alan öğrenme yöntemlerinden birisi de 'İşbirliğine Dayalı Öğrenme Yöntemi'dir.

\section{İşbirliğine Dayalı Öğrenme Yöntemi}

Düşünsel temeli oldukça uzun bir geçmişe sahip olan işbirliğine dayalı öğrenme yönteminin bugünkü anlamda kuramsal temelleri K. Koffka, J. Dewey, K. Lewin, J. Piaget ve L. Vygotsky çalışmalarına dayanmaktadır. Öğrenme üzerinde olumlu etkilerinin bilimsel araştırmalarla kanıtlandığı işbirliğine dayalı öğrenme yöntemi ulusal ve uluslararası eğitim literatüründe, eğitim, öğretim ve öğrenme sürecinde yerini almıștır. İşbirliğine dayalı öğrenme, İngilizce'de yaygın olarak "Cooperative Learning" ismiyle kullanılsa da bu kavramın karşılığı olarak "Work Group", "Collective Learning", "Learning Communities", "Team Learning", "Collobarative Learning", "Study Circles", "Study Group" ve "Team Work" gibi isimlerle de kullanıldığı görülmektedir. Bu kavramaların Türkçe karşıllı̆ı olarak "İşbirliğine Dayalı Öğrenme”, "İşbirlikli Öğrenme”, "İşbirlikçi Öğrenme”, "Kubaşık Öğrenme" gibi isimlerle dilimize çevrildiği görülmektedir. Konuyla ilgili başka bir farklılıkta bu kavramın model, strateji, yaklaşım ve yöntem olarak farklı şekillerle de isimlendirildiğidir. İşbirliğine dayalı öğrenme Türkçe literatürde öğrenme modeli (Demirel, 2007; Kaya, 2015), öğrenme yaklaşımı (Sönmez, 2008; Tan, 2006; Taşpınar, 2012), öğretim stratejisi (Güneş, 2014), öğrenme yöntemi (Açıkgöz, 2007; Tok, 2012) olarak da farklı kavramlar altında ele alınmıștır. Bunların yanı sıra işbirliğine dayalı öğrenme, bazı kaynaklarda "işbirliğine dayalı (işbirlikli) öğretim” olarak da geçmektedir (Ocak, 2011; Sünbül, 2011).

Öğretim sürecine yönelik felsefi bir bakış açısını yansıtan model, öğretimsel uygulamaların seviyesini ortaya koymaktadır (Taşpınar \& Atıcı, 2002). Strateji, öğretim amaçlarına göre uygulanacak yöntemlerin, materyallerin, araç-gereçlerin seçilmesine ve öğretimi yönlendirme etkinliklerine yol veren genel bir yaklaşımdır (Thuy, 2011; Legendre, 1988; Akt: Güneş, 2014). Yöntem; eğitimin hedeflerine ulamak amaciyla kullanılacak tekniklerin, işlenecek konunun, araç-gereç ve diğer kaynakların bütünlük oluşturacak biçimde organize edilerek hizmete sunulan düzenli bir öğretim yoludur ve öğretmenlerin sınıf içerisinde öğrenmeyi sağlamak için yaptıkları uygulamaları içermektedir (Clark \& Starr, 1968; Akt: Bilen, 2007). Başka bir tanıma göre, bir sorunu-problemi çözmek, bir deneyi sonuçlandırmak, bir konuyu öğrenmek ya da öğretmek gibi amaçlara ulaşmak için seçilen, takip edilen, izlenen yola yöntem denilmektedir (Demirel, 2007). Yöntem, stratejinin bir alt bileşenidir, nitelik yönüyle stratejileri uygulamaya koyan araçlardır, öğrencilerin bir konuyu öğrenmeleri için uygulanan çeşitli faaliyetlerdir (Güneş, 2014). Türkçe literatürde 'İşbirlikli ÖğrenmeÖğretim Modeli', 'İşbirlikli Öğrenme-Öğretim Yaklaşımı', 'İşbirlikli Öğrenme-Öğretim Stratejisi', 'İşbirlikli Öğrenme-Öğretim Yöntemi' gibi farklı isimlerle kavramsallaştırılmaktadır. Ancak model, yaklaşım, strateji ve yöntem kavramlarının teorik anlamlarından yola çıkıldığında ilgili kavramı “İşbirliğine Dayalı Öğrenme Yöntemi” olarak isimlendirmek de mümkündür. Öte yandan bu kavramın "öğrenme yöntemi” olarak kullanıldığına da literatürde (Açıkgöz, 1992; Açıkgöz, 2007; Ekici, 2007; Kaya, 2015; Özer, 2005; Yeşilyurt, 2009; Yeşilyurt, 2010) rastlanmaktadır. Bu çalışmada kullanılan “İşbirliğine Dayalı Öğrenme Yöntemi” yukarıda farklı isimlendirmeler altında yer alan tüm kavramları kapsayıcı bir şekilde ve aynı anlamda kullanılmaktadır.

İşbirliğine dayalı öğrenme, öğrencilerin ortak amaç doğrultusunda gruplar halinde çalışarak ve birbirlerinin öğrenmesine yardım ederek öğrenmeyi gerçekleştirme sürecidir (Açıkgöz, 2007). En genel ifadeyle eğitimin her aşamasında uygulanabilen ve öğrenci merkezli bir öğrenme yöntemi olan işbirliğine dayalı öğrenme, öğrencilerin bir öğrenme konusunda grup içerisinde heterojen, gruplar arasındaysa homojen bir yapıda, ortak amaç birliği içerisinde çalıştıkları, öğrenmelerini kolaylaştırdıkları, öz güven ve öz saygılarını yükselttikleri, iletişim, eleştirel düşünme, problem çözme ve sosyal becerilerini geliştirdikleri bir öğrenme yöntemi olarak tanımlanabilir (Varışoğlu, 2016). Öznesinin "ben" olduğu "ne yapmam gerekiyor, ne öğrendim, nasıl öğrenmeliyim" sorularının yerine 
öznesinin "biz" olduğu "ne yapmamız gerekiyor, ne öğrendik, nasıl öğrenmeliyiz" sorularının ön planda olduğu işbirliğine dayalı öğrenme yöntemi sadece bir grup çalışması değildir.

\section{İşbirliğine Dayalı Öğrenme Yönteminde Gruplar}

Sınıf içerisinde oluşturulabilecek birçok öğrenme grubu olabilir. İşbirliğgine dayalı öğrenme gruplan bunlardan biridir. Öğretimsel bir grup kullanılırken, öğretmen kendine "Hangi grup türünü kullanıyorum?" sorusunu yöneltmelidir. Aşağıda açıklanan grup türleri bu sorunun cevabını vermektedir (Kocabaş, Erbil \& Karaaslan, 2016; Yıldız, 1999).

1. Sahte (pseudo) öğrenme grubu: Bu tür öğrenme grubunda öğrencilerin birlikte çalışması amaçlanmıştır. Bu duruma karşı isteksiz olan öğrenciler performanslarına göre değerlendirilmekten yanadır. Birbirleriyle konuşuyor gibi görülseler de aslında birbiriyle yarışmaktadırlar. Birbirlerinden bilgi saklayabilir, birbirlerini şaşırtabilir veya yanıltabilirler. Etkili bir sonucun olmadığı böyle bir durumda öğrenciler yalnız başlarına çalıştıklarında daha başarılı olacaklarına inanabilirler.

2. Geleneksel öğrenme grubu: Öğrenciler birlikte çalışmak için yönlendirilmiş olup bireysel değerlendirileceklerine inanmaktadır. Öğrenme için birbirleriyle etkileşim içerisinde olmaları gerekirken bilgilerini grubun üyeleriyle paylaşma noktasında isteksizdirler. Yardımlaşma ve paylaşım en alt düzeydedir. Grupta yer alan bazı öğrenciler üzerlerine düşen görevleri yapmadan hazıra konma yoluyla grubun yaptığı işe ortak olmak isteyebilirler. Bu durumda çalışan öğrenciler kullanıldıklarını hissederek daha az çaba sarf etmeleri gerektiğini düşünerek pasif konuma düşebilirler. Sonuç olarak grubun ortaya koyduğu performans, bazı grup üyelerinin potansiyellerinin altında kalabilir. $\mathrm{Bu}$ durumda çalışkan ve dürüst öğrenciler, yalnız çalıştıklarında daha başarılı olacaklarına inanabilirler.

3. İşbirlikli öğrenme grubu: Ortak amaç doğrultusunda birlikte çalışmak için yönlendirilmiş olan öğrenciler bundan dolayı oldukça mutludurlar. Kendi başarılarının tüm grup üyelerinin çalışmasına, öğrenmesine ve başarılı olmasına bağlı olduğunun bilincindedirler. İşbirlikli öğrenme grubunun beş temel özelliği vardır.

Birinci özellik, tüm öğrencilerin öğrenme seviyelerini en üst düzeye çıkarma amacıdır. Her öğrenciyi ortak amaç doğrultusunda motive etmekte onların öğrenme düzeylerini yükseltmekte, kendi düzeylerinin ötesinde yeni şeyler başarmalarına olanak sağlamaktadır. Grup üyeleri, "Ya birlikte batarız ya birlikte yüzeriz." ve "Birimiz başarısız olursak, hepimiz başarısız oluruz." gibi düşünce anlayışına sahiptirler.

İkinci özellik, grup üyeleri kendilerinin ve grubun diğer üyelerinin, ortak amaçlara ulaşmak için işlerini yüksek nitelikte yapmaları gerektiğinin bilincindedirler.

Üçüncü özellik, grup üyeleri bir ürün ortaya koymak için öğrenme sürecinde yüz yüze etkileşim halinde çalışır ve gerçek anlamda "iş" yaparlar. Grup içerisinde yer alan öğrenciler birbirlerine yardım ederek, birbirleri ile paylaşarak, birbirlerine yardımcı olarak, açıklamalar yaparak, birbirlerini cesaretlendirerek her üyenin başarı düzeyini yükseltirler. Ayrıca öğrenciler çalışmanın başında verdikleri söze bağlı kalarak birbirlerine akademik ve sosyal yönden destek olurlar.

Dördüncü özellik, grup üyelerine sosyal beceriler kazandırılarak bu becerilerini, çalışmalarını düzenlemeleri, ortak amaçlara ulaşmaları doğrultusunda kullanmaları beklenir. Bireysel ve grup çalışması becerilerinin de vurgulandığı bu aşamada tüm öğrenciler gereken liderliği sağlamayı kabul etmektedirler.

Beşinci özellik, gruplar amaçlara ulaşırken kullandıkları öğrenme yöntemlerini, çabalarını ve çalışma süreçlerini analiz ederler. Sürekli gelişim ile öğrenmenin kalitesi ve grup çalışması süreçleri arasında bir ilişki bulunmaktadır. Grup, kendilerini oluşturan öğrencilerin toplamından büyüktür ve grup çalışması sonucunda, her öğrenci bireysel olarak ulaştığı en üst başarı düzeyinin de ötesine geçmektedir. 
4. Yüksek performanslı işbirlikli öğrenme grubu: Bu tür öğrenme grubu, işbirlikli öğrenme grubunun tüm özelliklerine en üst düzeyde sahiptir. Üyelerin birbirlerine olan bağımlılığ1, sorumluluğu, yardımı vb. üst seviyededir. Grup üyeleri aralarında kuvvetli bir duygusal bağ bulunur. Birbirlerine karşı anlayışlarının ve empatilerinin çok üst seviyede olması onları grup dışında gelişen olay ve konulara karşı da duyarlı hale getirmektedir. Grup dışında da değerli veya ihtiyacı olan biriyle karşılaştıklarında ilgilenir ve onlara yardım ederler. Genellikle beklenilenin oldukça üzerinde bir başarı sergileyen grup aynı zamanda çalışmalarından da büyük keyif alır. Yüksek performanslı işbirlikli öğrenme grubuna öğrenme ortamlarında çok az rastlanılmaktadır. Şekil 1'de grup türlerine göre grup performansının değişim grafiği yer almaktadır.

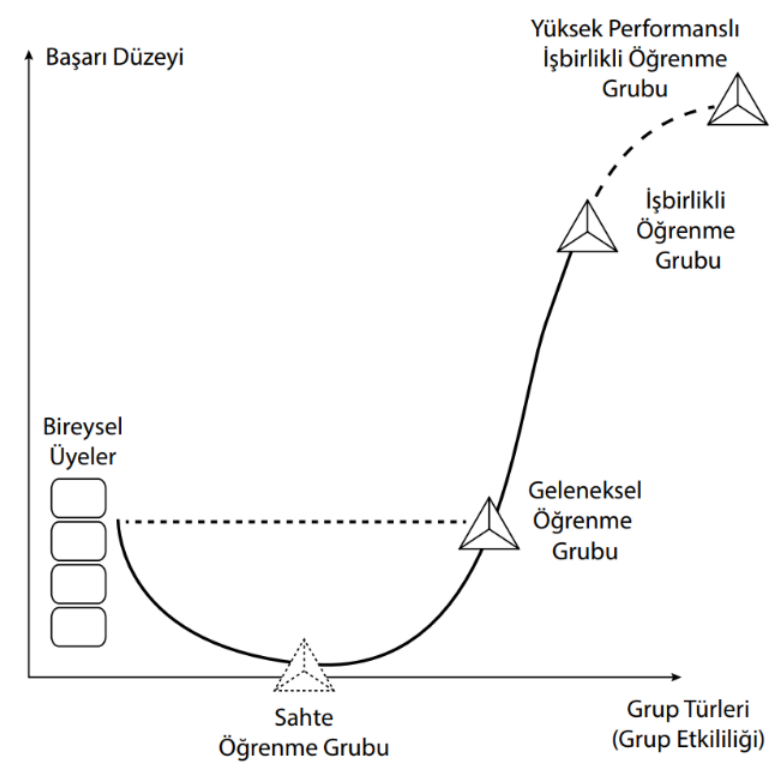

Şekil 1. Grup türlerine göre grup performansının değişim grafiği (Kocabaş, Erbil \& Karaaslan, 2016).

Bu bağlamda işbirlikli ve geleneksel öğrenme grupları arasındaki temel farklar şu şekilde özetlenebilir (Y1ldı, 1999):

1. Geleneksel öğrenme grubunda lider vardır, işbirlikli öğrenme grubunda ise liderlik grup içerisinde paylaştırılır.

2. Geleneksel öğrenme grubunda bireysel sorumluk, işbirlikli öğrenme grubunda ise grup sorumluluğu esastır ve üyeler birbirlerinin öğrenme sorumluluğunu üstenirler.

3. Geleneksel öğrenme grupları homojen yapıdadır. Heterojen yapıda olan işbirlikli öğrenme gruplarındaysa gruplar sosyal ve kişilik özellikleri, yetenek, cinsiyet, ırk vb. değişkenler açısından karmadır.

4. Paylaşma, iletişim, liderlik, karar sürecine katılım, çatışma çözümü, dürüstlük gibi sosyal becerilere geleneksel öğrenme gruplarında daha az, işbirlikli öğrenme gruplarında daha çok yer verilir.

5. Öğretmenin rolü geleneksel öğrenme gruplarında sınırlıdır. İşbirlikli öğrenme gruplarında öğretmen hem gözlemci hem de katılımcıdır. Sorunları çözer, grupların öğrenme sürecinin daha etkili ve nitelikli işleyebilmesi için gerekli işlemleri yapılandırır ve rehberlik eder.

6. İçerisinde amaç, rol, sembol, tanıtım, ödül, kaynak, görev ve tepki bağımlılığının da yer aldığı "olumlu bağımlılık" geleneksel öğrenme gruplarında gözlenmez, ancak işbirlikli öğrenme gruplarında görülür. 
7. Geleneksel öğrenme grubunda bireysel çalışma ön plandadır. İşbirlikli öğrenme grubunda ise her üyenin üst seviyede öğrenebilmesi için üyeler arasında iyi çalışma iklimi, atmosferi ve dayanışma bulunur. İş ve devamlılık önemsenir, gruptan çıkmış ortak ürüne vurgu yapılır.

\section{İşbirliğine Dayalı Öğrenme Yönteminin Temel İlkeleri}

İşbirliğine dayalı öğrenmenin amaca hizmet etmesi ve yararlarının uygulamada yerini bulması için bu yöntemin belli ölçütlere, ilkelere dayalı olarak uygulanması gerekmektedir. Bu ilkeler temel alınarak işbirliğine dayalı öğrenmenin yarışmacı ve bireysel çabalardan daha verimli olması beklenmektedir. Bu bağlamda birden fazla öğrenenin bir araya gelerek oluşturdukları birlikteliğin veya grup çalışmasının işbirliğine dayalı öğrenme olabilmesi için şu şartları (ilkeleri) sağlaması (taşıması) gerekmektedir (Aydal, 2017; Ekici, 2007; Türkmen \& Atasayar Yamık, 2015):

1. Olumlu bağımlılık (pozitif dayanışma): Bireylerin veya takımların ortak bir amaç için pozitif olarak bir araya gelmeleri gerekmektedir. Bunun sağlanması aynı zamanda, grup içerisindeki bireysel işlerinde birbirinden yararlanmasını sağlamaktadır demektir. Olumlu dayanışma işbirliğine dayalı öğrenme yönteminin en önemli ilkesi bir bakıma kalbi sayılmaktadır. Grup içerinde yer alan öğrenciler birlikte yüzeceklerine veya batacaklarına inanmalıdırlar. Grup içerinde yer alan her öğrenci çabasının gruptaki diğer öğrencilere ve gruptaki diğer öğrencilerin çabalarının da kendisine faydalı olduğunun ve katkı sağladığının bilincini taşımalıdır. Grubun başarısı grupta yer alan üyelerinin her birinin öğrenme amaçlarını gerçekleştirmesine bağlı olduğu unutulmamalıdır. Grup üyelerinden birisinin dahi başarısız olursa grubun tamamının başarısız sayılacağını öngörülmektedir.

2. Bireysel (kişisel) sorumluluk: Grupta yer alan her öğrencinin, öğrendiği bilgilerin diğer öğrenciler tarafindan da öğrenilmesi ve paylaşılması için aldıkları sorumluluklarda uzmanlaşması, bir bakıma bilgiyi tam öğrenmesi beklenmektedir. İşbirliğine dayalı öğrenme gruplarının en önemli amac1, grupta yer alan her üyenin bilgi, beceri ve davranış bakımından güçlü bireyler olmasını ve bireysel nitelikleri derecesinde grubun ortak amacının gerçekleşmesine katkı sağlamasını amaçlamaktadır. Her birinin üzerlerine düşen görevi en iyi şekilde yerine getirmesi gerekmektedir. Grupta yer alan üyeler sorumluluklarını yerine getirmeden grubun başarısına ortak olunamayacağının, bir bakıma hazıra konulamayacağının farkında ve bilincinde olmalıdır.

3. Yüz yüze (destekleyici) etkileşim: Grup üyelerinin birbirlerinin başarılarını kolaylaştırması ve desteklemesi demektir. Grup üyeleri "etkili ve yeterli çalışabilmek için birbirine yardım eden, önemli bilgileri ve materyalleri paylaşan, gelecekteki performanslarını geliştirmek için geri bildirim sağlayan, daha etkili düşünmeyi ve daha nitelikli ürünü teşvik edebilmek için fikir tartışmalarına giren ve grup amaçlarının gerçekleşmesini sağlayan" bireyler olarak öğrenme sürecini birlikte işletmelidirler.

4. Başarı için eşit fırsat: Farklı gruplardaki her öğrencinin başarıya ulaşmada tüm arkadaşlarıyla eşit şartlara sahip olduğunu ifade eden bir ilkedir. Bireyler, performanslarını yükselterek grubun ortak başarısına katkıda bulunmalıdırlar. Bu ilke, düşük, orta ve yüksek başarılı öğrencilerin kendilerinden beklenilenlerin en iyisini yapmalarını ve grup üyelerince önemli görülmelerini sağlar.

5. Kişilerarası ve grup (sosyal) beceriler: İşbirliğine dayalı öğrenme gruplarında öğrenciler, hem akademik konuları hem de grubun bir ekip ruhuyla çalışmasını gerektiren kişilerarası veya sosyal becerileri öğrenmekle sorumludurlar. Bu nedenle grup olarak çalışmak için, öğrencilere akademik becerilerinin yanında liderlik gibi interaktif yeteneklerini, iletişim, karar verme, karşılıklı güven oluşturma, yapıcı eleştiri, cesaret, uzlaşma, müzakere ve herhangi bir çatışma durumunu yönetmek gibi yeterlilikler de amaçlı, sistemli ve açık bir şekilde grup üyelerini tamamına kazandırılmalıdır. 
6. Heterojen gruplar: İşbirliğine dayalı öğrenme grupları akademik başarı puanları, cinsiyet, etnik köken, yaş, sosyo-ekonomik düzey gibi özellikler göz önünde bulundurularak heterojen gruplar oluşturulmalıdır. Bu durum işbirliğine dayalı öğrenme yönteminin uygulanmasında oldukça önemli bir ilkedir. Burada dikkat edilmesi gereken önemli nokta, grup içerisinde yer alan öğrencilerin heterojen yapıda olmasıdır. Gruplar arası homojen şekilde yapılandırılmalıdır. Bir bakıma değişkenler açısından grupların özelliklerin aritmetik ortalamaları birbirlerine yakın değerde olmalıdır. Kısaca grup heterojen, gruplar homojen yapıda olmalıdır. Grupta yer alan öğrenci sayıları çeşitli değişkenler dikkate alınarak değişebilir. Ancak ortalama 3-5 kişi ideal sayı olarak görülmektedir.

7. Grubun kendini ve süreci değerlendirmesi: Bu ilke, grup üyelerinin bireysel ve grubun hedeflerini gerçekleştirme düzeyinin değerlendirmesini ve ortak çalışma becerilerinin geliştirilerek sürdürülmesi anlayışını savunmaktadır. Grup, hangi etkinliklerin yararlı ve hangilerinin yararsız olduğuna, hangi etkinliklere devam edilmesi, hangilerinin değiştirilmesi gerektiğine tartışarak karar vermelidir. Bu değerlendirme grup üyelerinin öğrenme etkinliğinden en yüksek verimi elde etmelerini sağlayacağı gibi üyelere grup bilincini ve birlikte çalışma alışkanlığını da kazandırır.

8. Ödüller: İşbirliğine dayalı öğrenmede ödüller pekiştireç görevi üstlenir. Motive etmek amacıyla kullanılan ödüllerin verilmesinde öğrencilerin görevlerini yerine getirmeleri veya bir konunun öğrenilmesi, başarı elde etmek için önceden belirlenen bir ölçüte ulaşması gerekmektedir. $\mathrm{Bu}$ şartlar altında verilen ödüller öğrencilerde yapıcı rekabet duygusunu geliştirir, grup ruhu oluşturarak daha etkili çalışmalarını yardımcı olur.

9. Post-grup yansıması: Grup tarafından gerçekleştirilen etkinlik ve çalışmalardan sonra öğrenciler bunları diğer gruplarla paylaşırlar veya öğrendiklerini öğretmene yansıtırlar. $\mathrm{Bu}$ süreç; grupta yer alan hangi üyelerinin amaca ulaşmakta ne düzeyde katkı sağladığını, öğrenme sürecinde hangi davranış veya etkinlerin devam etmesi ya da değiştirilmesi gerektiği ve bir problemle karşı karşıya kaldıklarında öğrencilerin bu problemi çözmek hangi davranışları sergilediklerini değerlendirmesini içerir.

10. Öğretmenin rolü: İşbirliğine dayalı öğrenmede süreci öğretmenler yönetir. Grupların etkili çalışması, grup üyelerinin kendine verilen görevi yapması ve sınıfın yönetimi öğretmenin sorumluğundadır. Grup çalışmalarının etkili bir şekilde gerçekleşmesi için öğrenciler arası etkileşimin en üst düzeyde olması gerekmektedir. Bu nedenle öğrenciler arası etkileşimin en fazla olduğu öğrenme ortamını düzenleyecek ve öğrencilere öğrenme firsatı sunacak ortamı sağlayıcı konumda olan kişi öğretmendir. Amaçların (hedeflerin, kazanımların) belirlenmesi, grup oluşumu, gerektiğinde rollere atama, sınıfı düzenleme, akademik görevleri açıklama, başarı ölçütlerini belirleme, gruplar arası işbirliğini, olumlu bağımlılığı yapılandırma, öğrenci davranışlarını ve süreci izleme, gerektiğinde grup çalışmalarına müdahale etme, grubun işleyişini, süreci ve öğrenmeyi değerlendirme konularında öğretmen rehberlik yapmaktadır.

\section{İşbirliğine Dayalı Öğrenme Yönteminde Kullanılan Teknikler}

İşbirliğine dayalı öğrenmenin birçok tekniği bulunmaktadır. Bu tekniklerin uygulamasında işbirliğine dayalı öğrenme yönteminin temel ilkelerine bağlı olmasıyla birlikte her bir teknikte öne çıkan farklı özellikler bulunmaktadır. Amaçta ve özde aynı olan bu tekniklerin uygulanış şekli dersin özelliğine ve benimsenen teknikler açısından farklılık arz etmektedir. İşbirliğine dayalı öğrenme yönteminde kullanılan tekniklere aşağıda yer verilmiştir.

\section{A) Birlikte Öğrenme}

Tüm teknikler arasında, işbirliğine dayalı öğrenme yönteminin felsefesine en yakın olan bu teknik David ve Roger Johnson tarafından geliştirilmiştir. Grubun ortak amacı, düşünce ve malzemelerin paylaşımı, iş bölümü ve grup ödülüdür. İlk uygulamaları sırasında öğrencilerin bir tek ürün ortaya koymak için grup halinde çalışması; düşüncelerini, malzemelerini paylaşmaları, sorularını 
öğretmenden önce birbirlerine sormaları; grup ediminin ödüllendirilmesi sağlanmıştır. Johnsonlar o zamandan beri bu teknik üzerinde fazla sayıda araştırma yapmışlar ve ortaya çıkan sonuçlara göre tekniği değiştirip güncelleştirmişlerdir (Rosoff, 1998; Akt: Aydal, 2017). Birlikte öğrenme tekniğinin uygulanması sırasında yer alması gereken işlemler (aşamalar) şu şekilde sıralanabilir (Johnson, Johnson \& Holubec, 1990; Johnson \& Johnson, 1991; Ak: Aç1kgöz, 2007):

1. Hedefleri belirleme: İşbirliği ve akademik beceriler şeklinde iki grupta ele alınan hedeflerden ağılıklı olarak akademik hedefler üzerinde durulmaktadır.

2. Grup büyüklüğü: Gruplarda yer alan öğrenci sayıs1 2-6 arasındadır. Grubun büyüklüğünü zaman, malzeme sayısı gibi etkenler belirler. Gruplar büyüdükçe grup içinde uyuşmanın sağlanabilmesi için öğrencilerin daha fazla sosyal beceriye gereksinimi olacaktır. Öğrenciler birlikte çalışma alışkanlığı edinene kadar iki üç kişilik gruplamaların yapılması yararlı olacaktır.

3. Öğrencileri gruplara ayırma: Burada dikkat çeken önemli nokta heterojen gruplar oluşturulmasıdır. $\mathrm{Bu}$ nedenle, grupla öğretmenler tarafından oluşturulabilir. Ayrıca, grupların birlikte çalışma süreleri de önemlidir. Öğrencilerin her zaman aynı grupta çalışması yerine farklı gruplarda çalışmalarına ağrılık verilmelidir. Sorun çıktığı zaman grubu dağıtmak yerine birlikte çalışma becerileri kazandırılmaya çalışılmalıdır.

4. Sınıfın düzenlenmesi: Etkili ve kolay iletişim kurmak açısında aynı grupta yer alan öğrencilerin birbirine yakın, grupların ise birbirlerini rahatsız etmemek için öğrenme mekânı elverdiği ölçüde birbirlerinden uzak oturmalıdır.

5. Öğretim malzemelerinin (içeriğinin) bağımlılık oluşturacak şekilde planlanması: $\mathrm{Bu}$ aşama özellikle işbirliğine dayalı öğrenme uygulamalarına yeni başlayan ve grupla çalışma becerilerini kazanmamış ögrencilerin katılımını sağlamak için gereklidir. Bunu sağlamanın bir yolu, her gruba öğrenme malzemesinden bir kopya vererek öğrencileri, o malzemeyi paylaşmak zorunda bırakmaktır. Bir başka yol ise öğrencilerin her birine öğrenilecek bilginin yalnızca bir bölümünü vererek öğrencilerin birbirlerine öğretmelerini sağlamaktır.

6. Grup üyelerine birbirlerine bağımlılı̆̆ı sağlayıcı roller verme: $\mathrm{Bu}$ ilke dikkate alındığında gruba şu roller verilebilir. Grubun ulaştığı sonuç ya da yanıtları, yeniden kısaca açıklayan, özetleyici; her öğrencinin öğrenilenleri tam olarak açıklayıp açıklayamadığını sınayan, denetleyici; üyelerin açıklama ya da özetlerindeki yanlışları düzelten, netlik denetçisi; yeni öğrenilenler ile önceki öğrenilenler arasında bağ kuran, bă̆ kurucu; grubun gereksinim duyduğu malzemeleri getiren, malzemeci; diğer gruplarla iletişim kuran, araştırmacı; grubun kararlarını ve grup raporunu kaleme alan, yazıcı; üyelerin katılımını artırmaya çalışan ve pekiştiren, özendirici; grubun ne derece iyi çalıştı̆̆ını değerlendiren, gözlemci.

7. Akademik işi açıklama: Neyin nasıl yapılması gerektiği öğrencilere bildirilmeli, açıklanmalı, bunların tüm öğrenciler tarafindan anlaşılması sağlanmalıdır.

8. Olumlu yönde amaç bağımlılığı oluşturma: Bu ilkenin uygulanması için öğrencilerden ortak grup ürünü istemek veya onlara grup ödülü vermek yararlı olabilir.

9. Bireysel değerlendirme: İşbirliğine dayalı öğrenme grubunda yer alan üyelerin katkısını sağlamak veya belirlemek için gerekli olan bir süreçtir. Sınavların bireysel olarak yapılması, ya rastgele seçilen öğrencilere grup çalışmasıyla ilgili sorular sorulması ve grup üyelerinin birbirlerinin çalışmasını düzeltmesi ya da grup notunun rastgele seçilen bir öğrencinin çalışmasına dayalı olarak verilmesi gibi önlemler bu noktada yardımcı olabilir.

10. Gruplar arasında işbirliğini sağlama: Grubun içerisinde olan işbirliğinin faydaları sınıfın geneline yayılabilir, öğrencilerin diğer gruplarda yer alan arkadaşlarına yardımcı olması sağlanabilir. 
11. Başarı ölçüttlerinin belirlenmesi ve açıklanması: İşbirliğine dayalı öğrenmede başarının değerlendirilmesi önceden belirlenmiş olan ölçütlere dayalı olmalıdır.

12. İstendik davranışları belirleme: İşbirliğine dayalı öğrenme işe vuruk olarak tanımlanmalıdır. Başlangıçta; "grupta kalma", "sessiz konuşma", "sırayla yapma", "birbirine adıyla seslenme" gibi davranışlar üzerinde durulabilir. Daha sonraki aşamalarda ise yanıtın nasıl elde edileceğini açıklaması, önceki ve yeni öğrenilenler arasında bağ kurması, herkesin öğrenmesini, katılmasını ve dinlemesini sağlama, düşünceleri eleştirme davranışlarının beklendiği vurgulanmalıdır

13. Öğrenci davranışlarını yönlendirme: Grubun çalışması sırasında öğretmen, öğrencilerin hangi noktalarda hangi sorunlarla karşılaşıtılarını saptamak için grupları gözler. $\mathrm{Bu}$ gözlem, öğrencilerin gösterdikleri istendik ve istenmedik davranışları saptamak amacıyla da yapılır. Bazı olumlu davranışlar şunlar olabilir: Düşüncelere katkıda bulunma, soru sorma, duyguları açıklama, dinleme, destekleyici olma, değişik düşünceleri kabul etmeye açık olma, grup üyelerine sıcak davranma, bütün üyelerin katılımının özendirilmesi, özetleme, anlaşılıp anlaşılmadığını kontrol etme, şaka yaparak gerilimi düşürme, grup çalışmasına yön verme vb. Gözlemci olarak öğrencilerden de yararlanılabilir. Gözleniyor olduğunu bilmek, öğrencilerin uygun davranışları gösterme eğilimini artıracaktır. Gözlemler, gözlem formu kullanılarak da yapılabilir.

14. Grup çalışmasına yardımeı olma: Açıklama yaparak, soruları yanıtlayarak, tartışarak öğrencilerin etkili öğrenmelerinde ve işbirlikli öğrenme sürecinin hedeflerine varmasında öğretmen yardımc1 olabilir.

15. İşbirliği becerilerini öğretmek amacıyla araya girme: İşbirliğine dayalı öğrenme gruplarının çalışması sırasında öğretmenin birlikte çalışmakta güçlük çeken öğrencilerin işbirliği yapmalarını sağlayacak öneriler getirmesi ve bu becerileri gösteren öğrencileri pekiştirmesi yararlı olacaktır. Gerekli olmadıkça araya girmek yarardan çok zarar getirebilir. Çünkü işbirliği grupları biraz uğraştıktan sonra sorunların üstesinden gelebilir. Öğretmen, ne zaman ve nasıl araya gireceğine duruma göre karar vermelidir. Bazen sorunun çözümüyle ilgili önerilerde bulunurken bazen de öğrencilere yaptıkları işi bir yana bırakıp sorunu çözmeye çalışmalarını söyleyebilir. Bütün beceriler gibi işbirliği becerileri de öğrenilen becerilerdir.

16. Dersi sonlandırma: İşbirliğine dayalı öğrenme sürecinin sonunda öğrenciler bu süreçte öğrendiklerini özetlemeli ve nerede kullanacaklarını bilmelidirler.

17. Nitel ve nicel yöntemlerle öğrenmeyi değerlendirme: İşbirlikli öğrenme süreci sonunda ulaşılan ürün; grup raporu, grupça hazırlanmış bir dizi yanıt ya da öğrencilerin sınav puanları gibi bazı ölçümler olacaktır. Ölçüm ne olursa olsun öğrenme sürecinin sonunda öğrencilerin öğrenmeleri ve işbirliği becerileri değerlendirilmelidir.

18. Grubun ne kadar iyi çalıştığını değerlendirme: Zaman açsından maliyetli olsa da işbirliğine dayalı öğrenme sürecinden sonra grupta nelerin iyi yapılıp yapılmadığı değerlendirilmelidir. Zaman sorunu yoksa grupların süreçte edindikleri deneyimlerini diğerleriyle paylaşabilmeleri için değerlendirme sınıfça yapılabilir. Uygun zaman aralıklarıyla değerlendirme yapılmazsa öğrencilerin grup çalışma becerilerini edinmeleri zorlaşabilir. Bunu sonradan gidermek daha fazla zaman gerektirebilir.

19. Akademik çelişki oluşturma: Akademik çelişki, iki ya da daha fazla sayıda kişinin bilgilerinin, düşüncelerinin, sonuçlarının vb. birbiriyle uyuşmamasıdır. İşbirliğine dayalı öğrenme gruplarında öğrenciler arasında hangi cevabın verileceği ve grubun nasıl çalışacağı gibi konularda eski ve yeni öğrenilen bilgiler açısından grup üyeleri veya gruplar arasında, anlaşmazlık çıkabilir. 


\section{B) İşsirliği İşbirliği}

Spencer Kagan'nın geliştirdiği bu tekniğin özelliği, detaylı yönergelere sahip olması ve işbirlikli öğrenme hakkında yeterli bilgiye sahip olmayan öğretmenler tarafından dahi kolayca uygulanabilmesidir. $\mathrm{Bu}$ tekniğin felsefesini, eğitimin öğrencilerin doğal merakını, zekâ ve yeteneklerini ortaya çıkarıcı ve geliştirici bir role sahip olması gerektiği anlayışı oluşturmaktadır (Koç, 2014). Bu teknik, merakın, yeni yaşantılar geçirmenin, bunları da başkalarıyla paylaşmanın zevkli olduğu sayıltısına dayanmaktadır. Bu bakımdan işbirliği-işbirliği öğrenme tekniği, öğrencilerin önce kendilerini ve dünyayı anlamalarını sonra da bu deneyimlerini işbirliği içerisinde diğerleriyle paylaşmalarını sağlayacak biçimde düzenleyen sade, basit ve esnek bir öğrenme tekniğidir. İşbirliğiişbirliği çok çeşitli durumlarda ve konu alanlarında kullanılabilir bir tekniktir. Örneğin, geleneksel olarak işlenen bir konuyu tamamlamak ya da 10-15 dakikalık bir hazırlık aşamasından sonra 5 dakikalık sunum yapmak için kullanılabilir. Bu teknik bazı durumlarda tez, deney, slayt gösterisi vb. bir formal ürün olabileceği gibi, bazı durumlarda da yalnızca grup tartışmasını izleyen bir duygu paylaşımı biçiminde uygulanabilir. Bu tekniğin başarılı olması için bazı öğeleri kapsaması gerekir. Bu öğeler ve öğelerin genel özellikleri aşağıda yer almaktadır (Açıkgöz, 2007):

1. Öğrenci merkezli sınıf tartışması: Ünitenin veya konunun başında, öğrenciler işlenen konuya duydukları ilgiyi keşfetmek ve açıklamak üzere teşvik edilir. Önceden yapılan sunumlar ya da okumalar öğrencinin merakını uyandırmada etkili olacaktır. Sınıf tartışmasının amacı, ilgili konu hakında öğrencilerin öğrenmek istediklerini ortaya çıkarmaktır. Bu teknikte öğrenme, önceden belirlenmiş olan bir amaç doğrultusunda değil öğrencilerin ilgileri doğrultusunda oluşmaktadır. Böylece öğrenciler öğrenmeyi bir konu hakkında daha fazla bilgi edinme firsatı olarak göreceklerdir. Ayrıca, öğrenciler kendi öğrenmelerinin sınıf arkadaşlarına da yararlı olacağını görecektir.

2. Öğrenci takımlarının seçimi: Amaca göre öğrenciler ya takımlara atanırlar ya da takımları kendileri oluştururlar. Heterojen gruplar oluşturmaya çalışmalıdır. Eğer önemli olan öğrencilerin ilgilerinin geliştirilmesi ise öğrencilerin kendi gruplarını seçmelerine izin verilebilir. Ancak bu durum, sınıfta kutuplaşmalara yol açabilir.

3. Takımların oluşturulması: $\mathrm{Bu}$ aşamada birçok amaca hizmet edilebilir. Bunlar arasında; öğrencilerin tanışması, öğrencinin değerli olduğunu göstermek, üyeler arasında güven duygusunu geliştirmek, etkili grup etkileşimi, olumlu bağımlılık, takım kimliğinin kazanılması ve öğrencilerin kendilerini rahat hissedecekleri bir hava yaratmak yer alabilir.

4. Takım konusunun seçimi: Bu seçim, daha önceki sınıf tartışması sırasında bütün sınıfın ilgisine göre oluşturulmuş olan konu listesine bakılarak yapılır. Takımlar, ilgi duyduğu konuyu seçmek için tartışırken öğretmen öğrencilere yardımcı olmaktadır. Eğer iki takım aynı konuyu seçmek isterse, takımların ya konuyu ikiye bölerek ya da başka bir konu seçerek anlaşmaları istenir. Eğer hiçbir takımın seçmediği, ancak çalışılması gereken bir konu varsa takımlar o konuyu seçmek üzere teşvik edilir. Konular paylaşıldıktan sonra, öğretmen her alt konunun bir araya gelerek bir bütün oluşturacağına ve bunun ne kadar önemli olduğuna dikkat çeker.

5. Bireysel konuların seçimi: Takım içinde işbirliğini sağlayabilmek için takımın aldığı konu daha alt konulara ayrılır ve takımdaki her öğrenci bu alt konulardan birini hazırlamayı üslenir. $\mathrm{Bu}$ aşamada öğretmen, alt konuların eldeki kaynaklarda bulunanlar arasından seçilmesine ve öğrencilerin düzeyine uygun bir dağılım yapılmasına özen gösterir. Bazı öğrencilerin takım çalışmasına daha fazla katkıda bulunması olağandır. Ancak, herkesin eşit olmasa bile önemli katkılarda bulunması sağlanmalıdır. $\mathrm{Bu}$ durum a) takım üyelerinin birbirlerinin katkılarını değerlendirmesi, b) her öğrenciye mini konusuyla ilgili bir projenin verilmesi, c) öğretmenlerin bireysel katkıları sağlayacak yönlendirmelerde bulunması yollarıyla sağlanabilir.

6. Alt konuların hazırlanması: Bu aşamada öğrenciler, kaynaklardan yararlanarak seçtikleri alt konu ile ilgili bilgi ve malzeme toplarlar ve onları örgütlerler. Öğrenciler, yapacakları hazırlığın 
kendisi için olduğu kadar konunun bütünlüğü için de önemli olduğunu bilir. Konular hazırlanırken kütüphane çalışması, veri toplama, bir proje hazırlama, uzmanlarla görüşme vb. etkinliklerde bulunurlar.

7. Alt konuların sunumu: İşbirliği-işbirliği için son derece önemli bir aşamadır. Takım içindeki sunum ve tartışma, takım üyelerinin konu hakkında onunla ilgili tartışmaları sürdürebilecek düzeyde bilgilenmesini amaçlar. Sunumdan önce öğretmen aktif dinleme, görüşme ve destekleyici soru sorma ilkelerini gözden geçirebilir. Takım içerisinde; not alma, eleştiri, mini konular arasındaki uyumun kontrolü vb. roller paylaştırılır. Tartışmadan sonra öğrencilere, kendi çalışmalarını tartışmanın 1şı̆̆ında gözden geçirmeleri ve takımın mini konuları birleştirecek yeni bir malzeme üretmesine katkıda bulunacak bir rapor hazırlamaları için zaman tanınır.

8. Takımların sunum için hazırlanması: Öğrencilerin alt konu sunumu ile takım sunumunu ayırt etmeleri önemlidir. Örneğin, takımın topladığı malzemelerin paylaşımı tartışma konusu olabilir. Bu tartışma, konunun iyi kavranması ile kendiliğinden çözülebilir. Takımlardan, sunacaklarını açıklığa kavuşturmaları istenilir. Onlara tanınan süre bildirilir ve sunumlarını ilginç duruma getirmeleri, düz anlatım dışında, tartışma, gösterim vb. etkinliklerin ve değişik araçların kullanılması ile bütün sınıfın katılımının sağlanması teşvik edilir.

9. Takım sunumları: Öğrenciler sunumları esnasında sınıfın kontrolünü de sağlamaktadır. Öğrenciler sınıfı istedikleri gibi düzenlerler. Sunum sırasında zaman kullanımı önemlidir. Takımların sürelerini aşmamaları için sınıftan bir öğrenci zamanı kontrol etmekle görevlendirilebilir. Takımlar, sınıftan gelecek soruları cevaplandırmak için sunum sonlarında biraz zaman bırakabilir. Bu sırada hem konuyla ilgili hem de takımın nasıl çalıştığı ile ilgili sorular tartışılabilir.

10. Değerlendirme: Sunumların, bireysel katkıların öğrenciler ve öğretmen tarafından değerlendirilmesidir. Değerlendirme sırasında içerik ile sunumun en güçlü ve en güçsüz yönleri saptanır. Bunun için öğretmenin öğrencilerin de katkısını alarak geliştireceği değerlendirme formları kullanılabilir. Ayrıca, alt konular veya bireysel projeler dikkate alınarak bireysel notlar da verilebilir. Böylece, hazıra konma etkisi önlenmiş olur. Dışsal ödül sisteminin uygulanıp uygulanmaması; öğretmenin karizmasına, konunun niteliğine, dışsal ödüllerin niteliğine ve öğrencilerin konuya olan ilgilerine bağlıdır.

\section{C) Takım-Oyun-Turnuva}

D. Vries ve R. E. Slavin tarafından alana kazandırılan işbirliğine dayalı öğrenme tekniğidir. $\mathrm{Bu}$ tekniğin temeli, öğrenci gruplarının kendi içerisinde konuya hazırlandıktan sonra grup temsilcilerinin turnuvada yarışmasına dayanmaktadır. Grupların temsilcileri tarafından oluşturulan turnuva takımları turnuvalarda birbiriyle yarışır. Bunun için konuya iyi hazırlanıp temsilcileri aracılığıyla diğer takımlarla turnuvada yarışan grup temsilcilerinin aldığı her doğru cevap takıma artı puan kazandırmaktadır. Uygulanma aşamasında ilk olarak takımlar (gruplar) oluşturulur. Her grup kendi içerisinde çeşitli çalışma yaprakları, sorular veya oyunlarla konuyu çalışır. Dersin, haftanın veya konu çalışmasının tamamlanmasının sonunda takımların temsilcilerinden turnuva takımları oluşturulur. Turnuvalar düzenlenir ve gerekli görüldügü zaman birden fazla turnuva düzenlenebilir. Turnuvaların düzenlenmesinde şu yol takip edilebilir. Birinci turnuva için takımların (grupların) en iyisi olan üç öğrenci, birinci turnuva masasına; başarı düzeyi onlardan sonra gelen diğer üç öğrenci ikinci turnuva masasına; başarı düzeyi daha da sonra gelen öğrenciler ise üçüncü ve dördüncü turnuva masalarına yerleştirilirler. Turnuva masalarının bu şekilde oluşturulmasında temel amaç her turnuva masasındaki başarı düzeyi birbirlerine yakın takım temsilcilerini birbiriyle yarıştırmak, her öğrencinin başarı düzeyi ve gayreti oranında takımlarına katkıda bulunmasını sağlamaktır. Bu süreci takiben birinci haftadan sonra ortaya koydukları başarı düzeylerine göre öğrenciler masa değiştirebilirler. Başarısı yükselenler daha üst masalara, başarısı düşenler daha alt masalara geçerken başarısı aynı kalan öğrenciler aynı masada kalırlar. Temsilcilere sorulacak soruların numaralarının olduğu bir deste 
kart turnuva öncesinden hazırlanır. Grup temsilcileri (yarışmacılar) soruların numaralarının yazılı olduğu kartları çeker, çekilen kartın numarasına göre sorular sorulur. Soruyu doğru cevaplayan yarışmacı grubuna artı, yanlış cevaplayan ya da cevaplayamayan yarışmacı grubuna ise eksi puan verilir. Eğer yanlış cevaplanan soruya diğer yarışmacılar doğru cevabı verirse ilgili yarışmacının takımı (grubu) artı puanı almış olur. Ancak eğer bu yarışmacı yanlış cevap verirse kendi sorularına yanlış cevap vermediği için (diğer yarışmacının bilemeği soruları cevapladığı için) ilgili yarışmacının grubu eksi puan almaz. Burada dikkat edilmesi gereken önemli nokta, her yarışmacı öncelikle ve ilk olarak doğrudan kendi sorularını cevaplamakla sorumludur, cevaplayamadığı veya yanlış cevap verdiği durumlarda eğer cevaplama talebi varsa başka grupların temsilcisine söz hakkı tanınabilir. Turnuva sonunda yaş ve eğitim seviyesine göre takım başarısı ödüllendirilir (Açıkgöz, 2007; Maden, 2011a; Slavin, 1995).

\section{D) Takım / Küme Destekli Bireyselleştirme}

Küme destekli bireyselleştirme tekniği Slavin tarafından geliştirilmiştir. İşbirlikli öğrenme gruplarında bireyselleştirilmiş konular üzerinde çalıştığı ve grup başarısının önemli görüldüğü bir tekniktir (Slavin, 1984). Küme destekli bireyselleştirme tekniği öğrencilerin önce bireysel olarak hazırlanmış materyallerdeki problemleri ortalama dörder kişilik kümelerde çözmelerine, kümelerde karşılıklı olarak birbirlerinin yanıtlarını karşılaştırıp değerlendirmelerine, ayrıca gelişmelerine bağlı olarak her materyali bitirdiklerinde arkadaşlarından ve öğretmenden yardım almalarına olanak tanıyan bir öğrenme tekniğidir (İflazoğlu, 1999). Küme destekli bireyselleștirme tekniğinin temel öğeleri (aşamaları) ve bu öğelerin genel özellikleri şu şekilde açıklanabilir (Gelici \& Bilgin, 2011):

1. Takımlar: Akademik başarı, cinsiyet vb. değişkenler dikkate alınarak ortalama 4-6 kişilik heterojen gruplar (takımlar, kümeler) oluşturulur.

2. Öğretmen anlatımı: Konuları öğrencilere öğretmen tarafından anlatılır, konunun kavramsal temellerini sunar ve birkaç tane örnek soru çözer.

3. Çalışma yaprakları: İçerisinde işlenen konuyla ilgili birbirlerine eş değer nitelikte olan ve ortalama dörder soru bulunan iki veya üç kutucuktan oluşur. Her öğrenci bireysel çalışma kâğıdını aldıktan sonra, önce bireysel olarak birinci kutucuktaki soruları çözer. Bu işlemi takiben yanında oturan arkadaşıyla kâğıtlarını değiştirerek birbirlerinin çözümlerini kontrol eder, denetler. Bu işlemler diğer kutucuklar için de aynen tekrar edilir. Öğrencilerden en az bir kutucuktaki soruların tamamını doğru bir şekilde cevaplamaları beklenmektedir.

4. İzleme testleri: Sorumlu oldukları çalışma yapraklarını tamamlayan öğrencilere o haftanın kazanımlarını içeren "İzleme Testi A" verilir. Testteki soruları bireysel olarak cevaplayan her öğrenci daha sonra birbirlerinin testlerini kontrol ederler. Ortalama $\% 80$ ve üstünde bir başarı elde eden öğrenciler doğrudan konu sınavı almaya hak kazanır. $\mathrm{Bu}$ oranın altında daha az başarı sergileyen öğrenciler ise "İzleme Testi A"ya eş değer olarak hazırlanan "İzleme Testi B"yi alırlar. Aynı işlemler ve süreç "İzleme Testi B" için de geçerlidir ve yapılır. Bu testte de ortalama \%80 başarıyı yakalayamayan öğrenciler çalışmalarına bireysel olarak devam eder.

5. Konu sınavı: Öğrenme sürecinin (genelde haftanın) son dersinde o haftanın kazanımları dikkate alınarak hazırlanmış ve kapsam geçerliği sağlanmış olan konu sınavı bireysel olarak yapılır. Öğrencilerin sınavdan aldıkları bireysel puanlar toplanır, toplanan küme puanı kümede yer alan öğrenci sayısına bölünerek her kümenin başarı puanı ve sırası tespit edilir.

6. Başarı sertifikaları: Başarıların sertifikalandırılmasında öğrencilerin bireysel başarıları değil önceden belirlenmiş ölçütleri karşılayan kümelere başarı sertifikası verilmektedir. 


\section{E) Grup Araştırması}

Grup araştırması S. Sharan ve R. Hertz-Lazarowits (1980) tarafindan geliştirilmiş olan işbirliğine dayalı bir öğrenme tekniğidir. Grup araştırması işbirliğine, ortak amac1 yerine getirme ilkelerine, bireylerarası diyaloğa, öğrenmenin duyuşsal ve sosyal yönlerine önem vermektedir. Aşamalarında öğrencinin durumuna, zamana ve ortama uygun değişiklikler yapılabilen grup araştırması altı basamaklı bir süreç olarak işletilmektedir (Açıkgöz, 2007).

1. Araştırma konusunun saptanması ve grupların oluşturulması: Öğretmen sınıfa geniş kapsamlı veya çok boyutlu bir konu sunar. Öğrenciler belirlenen konu hakkında araştırmaya başlamadan önce öğretmen sınıfa konuyla ilgili çeşitli materyaller getirir ve öğrencilerin bunları incelemelerini sağlar. Öğrencilerin de katılımı ile genel konu alt konulara ayrılır. Aynı konuyu çalışmak isteyen öğrenciler bir araya gelerek gruplar oluşturulur.

2. Araştırmanın planlanması: Araştırma problemleri öğrenciler tarafından formüle edilir. Araştırmanın nasıl yapılacağı, konunun ve alt konuların konunun hangi kaynaklardan araştıracağı, öğrenciler arasında iş bölümü öğrenciler tarafından organize edilir.

3. Araştırmanın gerçekleştirilmesi: Grup planları çerçevesinde araştırmanın yerine getirildiği bu aşamada grup üyeleri çeşitli kaynaklardan bilgi toplar, verileri analiz eder, değerlendirir ve sonuçlara ulaşır.

4. Rapor hazırlama: Gruplar sonuçları rapor haline getirir. Öğrenciler hem öğretici hem de sınıftaki diğer öğrencilerin dikkatini çeken bir rapor hazırlamaya çalışırlar.

5. Raporun sunulması: Grup araştırması tekniğinin bu aşamasında gruplar görsel, işitsel araç veya materyallerden de destek alarak sunumlarını sınıfla paylaşır.

6. Değerlendirme: Öğrenciler, grup sunumları hakkında dönüt vererek değerlendirmeye katılabilirler. Değerlendirilmesi gereken noktalar:

a) Öğrencilerin konuyu nasıl araştırdıkları

b) Problemlerin çözümünde bilgiyi nasıl uyguladıkları

c) Nasıl çıkarım ve yorumda bulundukları

d) Hangi sonuçlara ulaştıkları

şeklinde özetlenebilir. İki hafta öncesinden haber verilerek ve grupların kendi raporlarına dayanarak hazırladıkları sorular temelinde sınavlar yapılır. Öğrenciler de sınava hazırlanırken bu soruları dikkate alır ve sınava hazırlık aşamasında yanıtlarını diğer gruplarla tartışıp geliştirir.

\section{F) Birlikte Soralım Birlikte Öğrenelim}

Bu teknik Açıkgöz (1990) tarafından geliştirilmiştir. Birlikte soralım birlikte öğrenelim tekniğini aşamaları şu şekilde açılanabilir (Açıkgöz, 2007; Çavdar, 2016; Koç, 2014; Yıldız \& diğ., 2017):

1. Aşama: İlk aşamada diğer tekniklerde olduğu gibi öğrenciler grup içi heterojen ve gruplar arası homojen şekilde gruplandırılır. Grup üye sayısı 3-6 kişi arasında değişmektedir.

2. Aşama: Bu aşamada gruplarda yer alan her öğrenci çalışma konusuyla ilgili kısa okuma çalışması gerçekleştirir.

3. Aşama: Okuma aşamasının tamamlanmasını takiben bireysel soru hazırlama aşamasına geçilir. Soruların bilişsel alanın kavrama basamağı ve daha üst basamakları kapsayacak şekilde olmasına dikkat edilir. Öğrenciler hazırladıkları soruları kartlara yazar ve zamanı geldiğinde bu sorular gruplara sunulur. 
4. Aşama: Grup üyeleri bir araya gelerek bireysel soruları değerlendirir, soruların niteliğini artırmak amacıyla eleştiri ve düzenlemeler yapabilir.

5. Aşama: Bu aşamada grup sorusu yazılır. Grup sorusunun hazırlanmasında daha önceden var olan bireysel sorulardan yararlanılabilir. Grup üyeleri birlikte yeni sorular da yazabilir. Bunun yanı sıra birden fazla sayıda soru hazırlanabilir ve ortak kararla grup sorusu olarak bu sorulardan birisi seçilebilir. Soru kartlarına yazılan sorular ve gerekli görüldüğü durumlarda diğer gruplara gönderilmek üzere hazırda tutulur. Grupların sorularını hazırlamasından sonra grup sorularının diğer öğrenme gruplara gönderilmesi aşamasına geçilir.

6. Aşama: Bu aşamada, her gruba farklı bir grubun sorusu gönderilmektedir. Soru, gruba ulaştığında ilgili grubun sözcüsü soruyu sesli olarak sınıfa okur. Aralarında tartışıp soruyu cevaplayabilmeleri için gruba belli bir süre tanınmaktadır. Grup, yine sözcüsü aracılığıyla grubun ortak cevabını sınıfa sunar. Cevap diğer öğrenciler veya öğretmen tarafından değerlendirilir.

7. Aşama: Grup çalışmalarının tamamlanmasından sonra konu öğretmen tarafından kısaca özetlenebilir. $\mathrm{Bu}$ aşamada grup çalışmaların üzerinde durulmayan noktalara dikkat çekilebilir. Anlaşılmayan veya üstünde durulmayan noktalar hakkında genel bir tartışma başlatabilir.

8. Aşama: Sunumdan sonra öğrenciler bireysel sınava girer. Sınavdan alınan puanlar ile grubun daha önceden belirlenen ölçütlere göre aldıkları sunum puanları toplanarak grup puanı elde edilir. Gruplar birbiriyle yarışmaz veya başarı açısından sıralamaya konulmazlar, ancak her grup bir başarı puanı elde eder.

\section{G) Birleştirilmiş İşbirlikli Okuma ve Kompozisyon}

Stevens, Madden, Slavin ve Farnish (1987) tarafından geliştirilmiş bir tekniktir. Genellikle ilk ve ortaöğretim düzeyinde öğrenilmesi gereken temel beceriler arasında yer alan "okuma ve yazma" becerilerini kazandırmak için kullanılır. Bu teknik geleneksel okuma ve yazmada karşılaşılan sesli okuma, okuduğunu anlama, izleme, yazma ve dil becerilerindeki sorunların çözümüne daha fazla katkı sunmaktadır. Diğer bir deyişle bu teknik ilkokul ve ortaokul düzeyinde dil becerilerini, okumayı ve yazmayı öğretmek amacıyla düzenlenmiş kapsamlı programdır. $\mathrm{Bu}$ teknik dolaysız öğretim, birleştirilmiş dil becerileri ve yazma olmak üzere üç ögeden oluşur (Açıkgöz, 2007). Birleştirilmiş İşbirlikli Okuma ve Kompozisyon tekniğinin işlem sırası (aşamaları) şöyle sırlanabilir (Gömleksiz, 1993; Koç, 2014):

1. Aşama: Okuma seviyelerine göre öğrenciler homojen olarak ikili ya da üçlü okuma gruplarına ayrılır ve farklı seviyedeki başka ikili ya da üçlü okuma grubuyla takım haline getirilir.

2. Așama: Öğrenciler, farklı okuma gruplarındaki öğrencilerden ikişerli gruplar halinde oluşturulmuş gruplarda görevlendirilir. Öğretmen bir okuma grubuyla çalışırken diğer gruplardaki öğrenciler ikili alt gruplar halinde çalışır. Bu çalışmalarda, birbirleriyle; okuma, öyküyü özetleme, öykünün nasıl sonlanacağını yordama ile sözcük, heceleme, şifre çözme gibi etkinliklerde bulunurlar. Konu materyalleri genellikle öğretmenler tarafından verilen hikâyelerden oluşmaktadır. İlk başta hikâyeleri sessizce okuyan öğrenciler daha sonra sesli bir şekilde okumaya başlarlar.

3. Aşama: Okumaların bitmesini takiben grup üyeleri hikâyenin nasıl sonlanacağını kestirmeye ve tahmin etmeye çalışırlar. Ana fikri anlayıncaya ve diğer becerileri tam kazanıncaya kadar, kendi gruplarında çalışmaya devam ederler. Bunun yanı sıra grup üyeleri ortaklaşa taslak bir metin oluşturabilir, birbirlerinin hatalarını düzeltebilir, öyküyü en uygun hale getirebilirler.

4. Aşama: Takımlar başta okuma ve yazma olmak üzere görev ve ödevlerinin tamamında üyelerin gösterdiği performans ortalaması dikkate alınarak ödüllendirilir. 


\section{H) Öğrenci Takımları - Başarı Bölümleri}

Öğrenci Takımları - Başarı Bölümleri tekniği Slavin ve arkadaşları tarafından geliştirilmiştir. Tekniğin işlem sırası (aşamaları) ve aşamaları şu şekilde sıralanabilir (Bilgin, 2006; Bilgin, Aktaş \& Çetin, 2014):

1. Așama: Konu öğretmen tarafından genellikle düz anlatım ve tartışma yöntemleriyle sunulur ve ardından heterojen gruplar oluşturulur.

2. Aşama: Öğrenciler, takımlarında yer alan tüm arkadaşlarının konuyu tam öğrendiğinden emin olana kadar çalışırlar.

3. Aşama: Öğrenme konusuyla ile ilgili hazırlık soruları, okuma parçaları, problemler içeren çalışma kâğıtları dağıtılır. Öğrenciler öncelikle ikili olarak çalışma kâğıtlar üzerinde çalışır, bilgileri tartışır, sonuca varır ve sonucu çalışma kâğıdına yazarlar.

4. Aşama: Sonra tüm grup üyeleri birlikte çalışma kâğıtları üzerinde çalışır, birbirlerinin cevaplarını kontrol eder, tartışır, yanlışlarını düzeltir ve ortak bir karara varmaya çalışırlar. Soruları birbirlerine sorarak birbirlerinin sınava hazırlanmalarını sağlarlar. Grubun tüm üyeleri konuyu anlayana kadar bu işlemler devam eder. Bu teknikte öncelikle önemli olan ortak başarının sağlanması ve gruptaki herkesin konuyu öğrenmesidir.

5. Aşama: Çalışmalar bittikten sonra, çalışılan konu üzerine tüm öğrenciler bireysel olarak sınava tabi tutulurlar. Burada "bireysel puan" ve "takım puanı" olmak üzere iki puan hesaplanır. "Bireysel puan" öğrencinin o derse ilişkin önceden aldığ 1 not ortalamasından, öğrencinin bu sınavda aldığı not çıkarılarak ilerleme (erişi) puanının hesaplanmasıyla elde edilir. "Takım puanı", takımı oluşturan grup üyelerinin bireysel puanı toplanarak hesaplanır. Takım puanı ile takımların başarı sırası oluşturulur ve bu sıraya göre ilk iki veya üç grubun üyelerine ödül verilir. Gruba katkı sağlama oranlarına göre de grup üyeleri önceden belirlenmiş ölçütlere göre ödüllendirilirler.

\section{I) Akademik Çelişki /Anlaşmazlık}

Johnson ve Johnson tarafindan geliştirilmiştir (Johnson, 1997). Öğrencilerde problem çözme, bilgi değişimi, yaratıcılık, başarı ve hatırda tutma, öğrenme sürecine öğrenci katılımı sağlama gibi becerileri geliştirmek amacıyla kullanılan güçlü ve katılım sağlayıcı bir tekniktir. Bu teknik kritik düşünmenin ve akılcı sonuçlara ulaşmanın öğretiminde oldukça etkilidir. Akademik çelişki tekniğinin uygulanma aşamaların da şu işlemler takip edilebilir (Açıkgöz, 2007):

1. Grupları oluşturma: Bu aşamada öncelikli olarak öğrenciler, önce dört kişilik gruplara, sonra bu gruplar da her biri çelişen düşüncelerden birini savunmak üzere iki alt gruba ayrilır.

2. Çelişkiyi sunma: Önceden saptanan çelişkinin gruplara sunumudur. Çelişkiler, salt oluşturmuş olmak için oluşturulmaz. Tersine, tartışmaya açık, yanıtı belirsiz, iki görüşün de savunulacak tarafları olan konularda çelişki oluşturulur. Örneğin, "Osmanlıların en parlak dönemi 16. yüzyıl mıdır, 17. yüzyıl mıdır?" tarih derslerinde iyi bir çelişki örneği olabilir. Tıp alanında, bir senaryoda durumu anlatılan hasta "ameliyat edilsin mi, edilmesin mi?"; okunan bir parçadaki "kahraman doğru mu yaptı, yanlış mı?" türünden çelişkiler kullanılabilir.

3. Öneriler hazırlama: $\mathrm{Bu}$ aşamada öğrenciler, ikili gruplarda çalışırlar ve bilgilerini örgütleyip sonuçlar çıkarırlar. Taraflar kendilerine sağlanan kitap, makale vb. malzemelerin üzerinde çalışarak, kendi aralarında o görüşü nasıl savunacaklarını planlarlar, kendi savundukları görüşün doğruluğunu kanıtlayacak gerekçeler hazırlarlar.

4. Görüssleri sunma: $\mathrm{Bu}$ aşamada taraflar, savundukları görüşü ve bu görüşü neden savunduklarını izah ederler. Daha sonra, sunulan çelişkili durumda en iyi kararın veya en doğru tespitin ne olabileceği üzerinde tartışma yapılır. Bu aşamada öğrenciler kendilerine mantıklı gelmeyen 
sonuç ve bilgilerle karşılaştıkça kavramsal çatışma ve belirsizlik geçirir. Bu çatışma ve belirsizliğin sonucu olarak, öğrencilerde bilme ve daha doğruyu merakı oluşur. Bu durumda öğrenciler çelişkiyi çözmek için daha fazla bilgi öğrenmeye başlar. Bu durum araştırmalarla da kanıtlanmış, çelişki yaşayan öğrenciler bireysel çalışma yapan ya da uzlaşan öğrencilere göre daha fazla kaynak taramışlardır.

5. Savunma: $\mathrm{Bu}$ aşamada, taraflar ortaya koydukları görüşlerini savunur.

6. Karşıt görüşü anlama (alma): Karşıt görüşün ne olduğunu taraflar açıklar.

7. Karara varma: $\mathrm{Bu}$ aşamada beklenen, iki tarafın da ortak anlaşabileceği bir kararın verilmesidir. Bunun için öğrenciler kendi görüşlerini savunmaktan vazgeçip en iyi kanıtları özetleyip sentezleyerek bir anlaşmaya varırlar ve bir grup raporu hazırlarlar. Grubun üyeleri ise sınavlara bireysel olarak hazırlanırlar.

Akademik çelişki tekniği ile münazara karıştırılmamalıdır. Münazarada iki taraf birbirine karşıt olan görüşleri savunur ve sonunda bir kazanan grup ortaya çıkar. Ancak akademik çelişki işbirliği ve yarışma olsa da kaybeden veya kazanan yoktur, öğrenmenin gerçekleşmesi vardır. Grubun amacı, sorun üzerinde ortak bir çözüme ulaşmak, konunun her iki yönü ile ilgili de bilgi toplamak ve ortak bir grup raporu hazırlamaktır. Kendi düşüncesini savunan her öğrenci bunun neden en doğrusu olduğu konusunda eşini ve diğerlerini ikna etmeye çalışmaktadır. Sonuçta ortak bir karara vararak rapor hazırlanmaktadır (Efe vd., 2008).

\section{I) Okuma-Yazma-Uygulama}

İşbirlikli öğrenmenin okuma-yazma temelli süreçlerle birleştirildiği Okuma-Yazma-Uygulama tekniği ilk ve ortaokul düzeyindeki derslerin konuları için kullanışlı bir tekniktir. Bu teknik öğrencilerin kişisel veya grup olarak çeşitli kaynaklardan okuma çalışması yapmasını, pozitif bağımlılık oluşturmasını, var olan bilgileri üzerine yeni bilgileri yapılandırmasını, sosyal ve psikolojik becerilerini artırmasını sağlamaktadır. Ayrıca, öğrencilerin okuma, yazma ve uygulama yeteneklerini geliştirir. Okuma-Yazma-Uygulama tekniği üç ana kısımdan oluşmaktadır (Aksoy, 2011; Aksoy \& Doymuş, 2011):

1. Okuma aşaması: İlk aşamada konuyla ilgili belge, kaynak ve dokümanların grupça çalışılmaktadır. Öğrencilerin okuma aracılığıyla yeni bilgileri yapılandırma becerilerini artırmaları hedeflenmektedir.

2. Yazma aşaması: Bu aşamadaki temel amaç grupta yer alan her öğrencinin öğrendiklerini birlikte yazarak ortak grup ürünü oluşturmalarını, karara varmalarını ve birbirlerini dinlemeyi öğrenmelerini sağlamaktır. Grup üyeleri okuma aşamasında öğrendiklerini hiçbir kaynak kullanmadan hep birlikte yazıp ortak grup ürünü oluştururlar.

3. Uygulama aşaması. Bu son aşamanın temel amacını, grup üyelerinin birbirlerine karşı kendilerini daha iyi, net ve etkili ifade edebilmelerini sağlamak, grup karşısında konuşmaya çekinen öğrencileri gruba dâhil ederek onların gruba aktif katılımını sağlamak ve uygulama yapma becerilerini geliştirmektir. Gruplar tarafından hazırlanan rapor ve ürünlerin sunulduğu son aşamadır.

\section{J) Karşılıklı Soralım / Sorgulama}

$\mathrm{Bu}$ teknik farklı yaş düzeylerinde ve konu alanlarında kullanışlı bir öğrenme tekniğidir. Karşı1ıklı sorgulamaya dayalı öğrenme tekniğinde, özel materyal hazırlama ve test etme işlemine ihtiyaç duyulmamaktadır. Konu öğretmenler tarafından sunulduktan sonra öğrencilere nasıl sorular sorması gerektiğini anlatır. Öğrenciler ikili ya da üçlü gruplara ayrılan öğrenciler konu hakkında hazırladıkları soruları birbirlerine sorar ve cevap verirler. Bu teknik, öğretmenlerce oluşturulan soru kökleri aracılığıyla öğrencilerin birbirlerine soru sorma ve sorulan bu sorulara cevap verme etkinliklerini içeren bir öğrenme uygulamasıdır. Öğrencilere ipucu olması için öğretmen tarafindan şu 
soru köklerine dayalı sorular oluşturulabilir. Örneğin: “... Benzerlik ve farkl11ıkları nelerdir?” “...Nasıl kullanırdınız?” “... İlgili yeni bir örnek veriniz.” Bu tekniğin geleneksel tartışma yöntemine göre daha etkili olduğu ispatlanmıştır. Çünkü bu teknik öğrencilerin konuya ilişkin derinsel düşünmelerini ve konuyu daha derin öğrenmesini teşvik etmektedir (Dirlikli, 2015; Özyurt, 2013; Senemoğlu, 2005; Baykara, 2000).

\section{K) Birleştirme (Jigsaw)}

İlk kez Elliot Aronson tarafindan geliştirilen "Birleştirme-Jigsaw", daha sonra Slavin, Stahl ve Holliday tarafından yapılan çalışmalarla güncellenen işbirliğine dayalı bir öğrenme tekniğidir. Her güncelleme, bir bakıma bir önceki tekniğe yeni işlemler eklenme veya önceki teknikteki işlemlerin sırasında yer değişikliği yapılma durumuna göre bu tekniklerin uygulamalarında bazı farklılıklar vardır. Tekniğin en çok bilinenleri veya kabul görenler arasında; "Birleştirme-I, Birleştirme-II, Birleştirme-III, Birleştirme-IV, Ters Birleştirme ve Konu Birleştirme" teknikleri yer almaktadır. Birleştirme tekniklerinde öğrencilerin birbirilerine olabildiğince bağımlı olmaları planlanmıştır. Birleştirme teknikleri, parçaların birleştirilerek anlamlı bir resmin veya bir bütünün meydana getirildiği yap-boz oyununa benzemektedir. Bazı kaynaklarda "Ayrılıp Birleştirme" olarak çevrilen "Birleştirme", içerisinde farklı uygulamaları barındıran esnek bir yapıya sahiptir. Aşağıda "Birleştirme-Jigsaw" çeşitlerine yer verilmiştir.

Birleştirme-I (Jigsaw-I): Birleştirme I tekniği, Eliot Aranson (1978) tarafından geliştirilmiş olup Jigsaw tekniği olarak da adlandırılmaktadır. 5-6 kişiden oluşan gruplara ayrılan öğrencilerin (grupların) tamamı aynı üniteyi öğrenir. Birleştirme I, her bir öğrencinin akademik veya öğretici bir bulmacanın parçalarını oluşturduğu ve Jigsaw gruplarında birleşerek uzmanlaştığı işbirliğine dayalı öğrenme tekniğidir. Her bir öğrenci akademik veya öğretici bulmacanın diğer grup üyelerinin olduğu bölümlerinde öğrenir. Her bir öğrenci kaynak olarak gördüğü diğer grupların bilgilerini edinir ve edinilen bilgiler gruplar içerisinde paylaşılarak bilgiye bir bütün halinde ulaş1lır. Birleştirme I tekniğinin uygulanma sürecinde izlenecek aşamalar şu şekilde sıralanabilir (Köseoğlu, 2010; Maden, 2011b; Şimşek, 2007):

1. Asıl grupların oluşturulması: 3-7 kişiden oluşan gruplar tercih edilir.

2. Malzemenin bölünmesi: Grupta yer alan öğrenci sayısı kadar parçalara ayrılan konunun her parçası bir öğrenciye verilir.

3. Uzman gruplar: Birleştirme I tekniği için geçerli aşamadır. Gruplarından ayrılan öğrenciler aynı konuyu hazırlamakla sorumlu olan diğer öğrencilerle yeni gruplar oluşturur. 'Uzmanlık' grubu olarak adlandırılan bu gruplar, konuyu açıklığa kavuşturmaya çalışır, onu diğer arkadaşlarına nasıl öğreteceklerini planlar ve rapor hazırlarlar.

4. Uzman grupların asıl gruplarına geri dönüşü: Kendi gruplarına dönen öğrenciler konularını uzmanlık grubunda planladıkları gibi hazırladıkları raporlar vasıtasıyla arkadaşlarına öğretirler. Öğretmen, bu son aşama olan tamamlama aşamasında, öğrencilerin öğrenmelerini bir araya getirip bütünleştirmek için bireysel, küȩük grup ya da sınıfın tamamının katıldığı bir etkinlik düzenleyebilir. Örneğin asıl gruplardan birine konuyu sunmaları için bir gösteri sunusu yaptırabilir ya da kişisel sunular yaptırarak onların öğrenmeleri bütünleştirebilir. Değerlendirme sürecinde ise öğrenciler işbirliğine dayalı öğrenme yönteminde kullanılan değerlendirmeleri yaparak çalışmalar tamamlanır.

Birleştirme-II (Jigsaw-II): Birleştirme-II tekniği Slavin (1987) tarafından Birleştirme-I tekniğinde değişiklikler yapılarak geliştirilmiştir. Birleştirme-II öğrenme tekniğinin orijinal birleştirme tekniğinden ayrıldığı önemli nokta, ekip ruhu oluşturmak için kullanılan etkinliklerin olmaması ve grup liderinin bulunmamasıdır. Slavin'e göre bu iki birleştirme teknikleri arasındaki farklar aşağıdaki gibi özetlenebilir (Y1lmaz Güngör, 2011): 
a. Orijinal birleştirme (Jigsaw-I) tekniğinde, öğrenciler grup arkadaşlarından tamamen farklı olan bölümlerini bireysel olarak okurlar.

b. Orijinal birleştirme tekniğinde temel olan ders materyalinin kendi içerisinde bir bütünlüğü olacak biçimde yazılmasıdır. Öğrencilere dağıtılan bölümler konu olarak birbirinden farklılık göstermektedir.

c. Birleştirme-II'nin avantaj1 (üstün yönü) ise tüm öğrencilerin ders malzemesini hep birlikte okuma imkânına sahip olmasıdır. Bu durum aynı zamanda konunun tamamı hakkında onlara fikir vermektedir.

Birleştirme-II öğrenme tekniğinin kullanıldığı sınıf içi etkinliklerin düzenlenmesinde aşağıdaki sıralama dikkate alınabilir (Açıkgöz, 2007; Yılmaz Güngör, 2011):

1. Ders malzemesini (içeriğini) hazırlama: Eğer ders materyali sınıfta okunacaksa kısa metin seçilmelidir. Ancak, öğrencilerin evde çalışacakları bir materyal ise uzun okuma parçası da tercih edilebilir. Öğrencilere verilen çalışma yapraklarındaki sorular, okuma esnasında konuyu anlamaları açısından onlara yardımcı olabilir.

2. Öğrencileri başlangıç gruplarına ayırma: Bir liderin bulunmadığı ve 4-5 kişiden oluşan heterojen gruplarda yer alan her grup üyesine çeşitli roller verilir. Birleştirme II tekniğinde öğrencilerin başlangıçta ünitenin belli bir konusunu seçmesi yerine önce gruptaki öğrenciler ünitede yer alan tüm konuları okur, sonra uzmanlaşacakları konuyu seçerler.

3. Uzmanlık gruplarında çalışma: Metnin aynı kısmını çalışacak olan öğrenciler, tartışmak veya çalışma yapraklarındaki soruları cevaplamak amacıyla bir araya gelirler. Farklı gruplardan aynı konuda uzmanlaşacak öğrenciler, konuları tartışmak üzere "uzmanlık grupları"nda bir araya gelip konuları tam olarak öğrenmeye çalışırlar.

4. Başlangıç grubu raporu: Metnin aynı parçasını öğrenen uzmanlık grubu öğrencileri kendi bölümlerini çalıştıktan ve öğrendikten sonra başlangıç (ilk) gruplarına dönerler ve arkadaşlarına kendi parçalarını ögretirler. Konunun tam olarak anlaşıldığından ve kısa sınava girmeye hazır olduklarından emin olmak için tüm öğrenciler hep birlikte çalışırlar.

5. Sınav: Bireysel olarak sınava alınan öğrencilerin aldıkları nota gelişme puanı da eklenir. En yüksek notu alan grup üyeleri, gruplarına birincilik kazandırır. Öğrencilere ödül ve sertifika verilir.

Birleştirme-III (Jigsaw-III): Bu teknik Stahl (1994) tarafından geliştirilmiştir. Birleştirme-III tekniğinde ise Birleştirme-I ve Birleştirme-II tekniklerinden farklı olarak uygulama süreci standart formlarla değerlendirilmektedir. Öğrencilerin birbiriyle iletişimini artırmak için geliştirilen bu teknikte öğrenciler bireysel değerlendirilmeden önce kendi bölümlerinin ne derece öğrenildiğini belirlemek için değerlendirilirler. Diğer süreçlerde (aşamalarda) Birleştirme-II ve III ile benzer yapıya sahiptir (Maden, 2011b; Çelik, 2017; Kılınç, 2014).

Birleştirme-IV (Jigsaw-IV): Dwight C. Holliday (2000) tarafindan geliştirilen Birleştirme-IV tekniğinin diğer Birleştirme tekniklerinden ayıran en büyük özellik şudur. Birleştirme-IV tekniğin uygulaması konuya dikkat çekmek amacıyla etkinlik yapılmasıyla başlaması, uzman grup ve asıl grup çalışmalarının ardından iki ayrı mini sınav yapılmasıdır (Holliday, 2002; Akt: Doğru \& Ünlü, 2012). Diğer bir deyiş̧le Birleştirme-IV tekniğinin Birleştirme-I-II-III'ten farkı dersin ilk bölümünde konunun temel noktalarının öğretmen tarafından izah edilmesi, uzmanlık gruplarının kendi (asıl) gruplarına dönmeden önce sinava tabi tutulması ve uygulama sonunda yapılan sinavdan sonra konunun eksik yönlerinin öğretmen tarafından tekrar açıklanmasıdır (Bölükbaş, 2014; Maden, 2011b). Jigsaw-IV tekniğini geliştiren Holliday (2000; Akt: Bölükbaş, 2014) bu tekniğin uygulama aşamasındaki işlemleri şu şekilde sıralamaktadır: 
1. Grupların oluşturulması: 3-7 kişilik heterojen gruplar oluşturur. Öğrencileri motive etmek ve grup aidiyeti oluşturmak amacıyla grupların kendilerine birer isim koymaları sağlanır.

2. Konunun kısaca verilmesi: Öğrencilerin konuya dikkatini çekmek ve öğrencilerde farkındalık oluşturmak için öğretmen tarafından konu kısaca anlatılabilir ya da onlara konuyla ilgili kısa bir video seyrettirilebilir.

3. Uzmanlık gruplarının oluşturulması: İşlenecek konu, gruptaki yer alan öğrenci sayısı kadar bölümlere ayrılır ve her bölüm bir öğrenciye verilir. Öğrenciler, kendi gruplarından ayrılarak aynı konuyu hazırlamakla sorumlu olan diğer gruptaki öğrencilerle birleşerek "uzmanlık grupları" oluştururlar.

4. Uzmanlık grubu mini sınavlarının yapılması: Konularını çalıştıktan sonra, o konuda tam olarak uzmanlaşıp uzmanlaşmadıklarını anlamak için uzmanlık grupları sadece kendi konularından mini sınava tabi tutulurlar. Bu sınavın sonuçlarını dikkate alan öğretmen, konunun eksik kalan yanlarını gruplara açıklar ve varsa yanlışları düzeltir.

5. Öğrencilerin asıl gruplarına dönmesi: Bu aşamada öğrenciler asıl gruplarına geri döner. Her öğrenci kendi uzmanlık konusunu grupta yer alan diğer arkadaşlarına anlatır ve onları bilgilendirir.

6. Asıl grupların mini sınavlarının yapılması: Bu aşamada gruplar, "uzman öğrencilerin" diğer grup üyelerine konularını tam olarak öğretip öğretmediklerini sınamak amacıyla, konunun tüm bölümlerinden soruların yer aldığı mini sınav olurlar. Sınavın sonucunda eksik ya da yanlış olan bölümler öğretmen tarafından tekrar anlatılır ve yanlış, eksik öğrenmeler giderilir.

7. Bireysel ölçme ve değerlendirme: Tüm öğrenciler uygulamanın sonunda konunun tamamından bireysel olarak sınava alınırlar. Bu sınavın sonuçalarına göre konunun eksik kısımları ögretmen tarafindan tekrar açıklanır.

Jigsaw - Jigsaw II - Jigsaw III - Jigsaw IV teknikler arasındaki temel farklar: Tüm Jigsaw teknikleri, öğrencileri ait olduğu gruba, konunun bir parçasını öğretmekten sorumlu kılarak işbirliğine dayalı öğrenmeyi amaçlamaktadır. Bu tekniklerle yapılan etkinlikler, her öğrencinin kendi öğrendiklerini grubun diğer üyelerinden öğrendikleriyle bir araya getirerek anlamlı ve tutarlı bir bilgi bütünü oluşturmasına katkı sağlar. Bu yapı dikkate alındığında, tüm Jigsaw teknikleri öğrencilerin bilgiyi hem özerk hem de kendi kendini düzenleyecek bir biçimde edinmesini ve birbirlerine açıklamalar getirmesini sağlar. Jigsaw tekniklerinin temel ilkeleri benzer olmakla birlikte aralarında küçük farklılıklar bulunmaktadır. Jigsaw teknikleri arasındaki en büyük farklar öncelikle öğrencilerin öğrenmelerinin değerlendirilme şekli veya gruplar arası etkileşim derecesi ile ilgilidir (Bölükbaş, 2014). Jigsaw ve Jigsaw-II teknikleri arasındaki iki temel fark bulunmaktadır. Birinci temel farklılık, pozitif bağımlılık oluşturma ve süreç için çıktılarda görülmektedir. Jigsaw II tekniğinde öğrencilerden merkezi fikir, ana iskelet ya da önemli ünitelerin derinlemesine kavramsal anlaşılması için farklı açılardan incelenmesi yoluyla materyali ya da üniteyi özetlemeleri istenmektedir. İkinci temel farklılık ise grup başarılarının ödüllendirilmesi sürecinde ekstra bir ödül kullanımıdır. Jigsaw II tekniğinde düşük, orta ve yüksek performanslı öğrencilerden meydana gelen heterojen gruplar oluşturulur. Ünite bölümlerini birbirine öğreten öğrenciler sürecin sonunda ünitenin tamamından bireysel olarak sınava tabi tutulurlar. Öğrencilerin sınavlardan aldığı kişisel puanlar toplanıp grup puanına ulaşılır. Grup puanları, düşük puanlara sahip olan grup üyelerine etki yapmak sureti ile geliştirme puanları olarak kullanılır. Ortalama puanı yüksek olan gruplar farklı biçimlerde ödüllendirilir. Böylece gruplar arasında yarışmacı bir ortam oluşturularak grup elemanları arasında grup puanlarını yükseltmek amacıyla pozitif bir bağl11ık da meydana getirilmiş olur (Şimşek, 2007). Jigsaw-III tekniğinde ise diğer Jigsaw tekniklerden farklı olarak uygulama süreci standart formlar kullanılarak değerlendirilir. Ö̈te yandan Jigsaw-IV tekniğinin diğer Jigsaw tekniklerinden farkları ise dersin başında konunun ana noktalarının öğretmen tarafından açıklanması, uzmanlık gruplarının kendi gruplarına dönmeden önce

Turkish Studies - Educational Sciences

Volume 14 Issue 4, 2019 
sınava (quiz) alınarak öğrenmelerinin doğruluğunun kontrol edilmesi ve uygulamanın sonunda yapılan sınavdan sonra öğretmen tarafindan konunun eksik yönlerinin tekrar açıklanmasıdır (Maden, 2011b).

Ters Birleştirme / Ters Jigsaw: Bu teknik T. Hedeen (2003) tarafından geliştirilmiştir. Ters Jigsaw ile Jigsaw teknikleri öğretmen rolü, öğrencilerin gruplar halinde bir araya gelip sorumluluk sahibi olması ve konuları öğrenme yönlerinden benzerdir. Ancak Ters Jigsaw, işbirliğine dayalı öğrenmelerin farklı özelliklerini ortaya koyma ve başarma yönlerinden Jigsaw tekniğinden ayrılmaktadır (Hedeen, 2003). Ters Jigsaw ile Jigsaw (Jigsaw I) arasında karmaşık bir bağlantı bulunmaktadır. Ters Jigsaw'da öğretmenin rolü, her bir öğrencinin öğrenmeleri için sorumlulukları ile küçük grup tartışmalarını kolaylaştırması ve aynı grup yapısında görevler alması gibi bazı aşamalarda Jigsaw ile benzerdir. Ancak Ters Jigsaw amaçların çok farklı bir kısmını başarmak için dizayn edilmiştir. Bu noktada Jigsaw öğretilecek olan materyalin öğrenciler tarafından kavranmasına katkıda bulunmak anlamında gerçekleştirilirken Ters Jigsaw oldukça katılımcı bir yapı içerisinden çalışılacak konu başlıklarının biri üzerine kararlar almada ve kavramları oluşturmada daha fazla öğrenci yorumunu artırmak ve öğrenmelerini hızlandırmak bakımından farklılık göstermektedir. Ters Jigsaw'ın üç adımda açıklaması yapılabilir (Şimşek, 2007):

1. Adımda, öğrenciler dört kişilik heterojen gruplarda toplanır. Gruplardaki her öğrenciye kompleks bir soru ya da sorular ile örnek olay incelemesinden oluşan bir modül verilir. Her öğrenci konu başlı̆̆ 1 ya da soruları ile ilgili grup tartışmalarını hızlandırır. Bu süreçlerin sonunda her bir öğrenci ana temayı ya da tartışmalar sonundaki çıktıları yazar. Çalışma zamanı, öğrenme konusuna bağlı olarak yaklaşık 5-15 dakikalık zaman dilimine ayrılır.

2. Adımda, aynı başlığı çalışan öğrenciler başlığın çalışılmasını hızlandırmak ve bilgi kayıtları yapmak üzere başlık gruplarında toplanarak başlık grupları oluşturulur. $\mathrm{Bu}$ gruplarda öğrenciler konu başlıkları ile ilgili tartışmalarının en önemli kısmını paylaşırlar, ortak bir rapor hazırlarlar ve sınıfta farklı alıştırmalar yaparlar. Bu süreçler başlık gruplarının üniteleri için kısa sözlü sunumlar ve görsel bir rapor hazırlamalarına yardımcı olur. Başlık gruplarında bu aşamanın sonunda tartışılan konunun özelliğine bağlı olarak bir konuşmacı seçilir ve 10-25 dakikalık bir zaman alan tartışmalar tekrar yürütülebilir.

3. Adımda, sınıfın tamamı yeniden gruplandırılır. Gruplama işlemi, her bir başlık grubundan biri o ünite ile ilgili sözcü olmak üzere büyük bir gruba toplanır. Oluşturulan bu büyük gruplarda başlık gruplarından gelen öğrenciler raporlarını diğer arkadaşlarına vererek birbirlerinin raporlarını inceler ve birbirlerine sözlü sunumlar yaparlar. Öğretmen bu süreçte gerçekleşen tartışmaları, grup dinamiklerini yükseltmek ve incelemek için etkinlikler yapar. Süreçlerde bir aksaklık ve yanlış bir durum oluşmamış ise öğretmen değerlendirmeye geçerek kendi hazırlayacağı değerlendirme formları ile değerlendirme sürecini işletir.

Konu Birleştirme / Konu Jigsawı: Öğrenilmesi zor görülen bir konunun öğrenilmesinde etkili bir öğrenme tekniğidir. Doymuş (2007) tarafından geliştirilmiştir. Bu teknik beş aşamadan oluşmakta ve bu aşamaların genel özellikleri aşağıda yer almaktadır (Akkuş, 2013; Koç, 2014):

1. Aşama: Konunun ve uygulama süresinin özelliğine göre öğrenciler 2-6 kişilik heterojen gruplara bölünürler.

2. Aşama: Gruplardaki her öğrenciye konunun (ünitenin) bir alt başlı̆ğ verilir. Kendilerine verilen ve sorumlu oldukları alt başlığı araştıran öğrenciler bir rapor hazırlar. Öğretmen, hazırlıklarını kontrol etmek için gruplardan rastgele seçtiği öğrencilerin hazırladığı konuları sunmalarını sağlar.

3. Aşama: Gruplarda konularını çalışan öğrenciler, aynı konuları çalışmakta olan ama farklı gruplarda yer alan öğrencilerle bir araya getirilip yeni bir grup oluşturulur. Bu yeni grupta da öğrenci sayısı 2-6 kişi arasında değişir. Yeni oluşturulan gruplarda öğrenciler birlikte çalışarak raporlarını hazırlar. Çalışmaları kontrol etmek için gruplardan rastgele seçilen öğrencilere sunu yaptırılır. 
4. Aşama: Önceki aşamalarda çalışmalarını tamalayan öğrenciler asıl (başlangıçtaki) gruplarına geri döner. Farklı konu başlıklarını çalışmış ve öğrenmiş öğrenciler bir araya geldiği için ünitenin tamamını temsil eden öğrenciler bir araya gelmiş olurlar. Ünitenin tamamını birlikte çalışan öğrenciler üniteyi öğrenirler. Çalışmalar tamamlandıktan sonra öğrenci grupları öğrenmiş oldukları konuları sınıfa sunar.

5. Aşama: Değerlendirme aşamasında öğrenciler kişisel olarak sınav olurlar. Sınavda yer alan sorular alt konu başlıklarına göre gruplandırılır. Öğrencilerin verdiği cevaplar alt gruplara göre teker teker (ayrı ayrı) analiz edilir. Eğer bir öğrencinin herhangi bir alt başlıkta eksikliği veya yanlışı tespit edilirse, o alt başlığı öğrenmek için grubuyla birlikte yeniden çalışmaları sağlanır. $\mathrm{Bu}$ aşamada öğrenme eksiklikleri veya yanlışları olan öğrenciler grup arkadaşlarıyla birlikte çalışmalarını tamamlar. Bu süreci takiben öğrencileri, öğrenme eksikliklerinin tespit edildiği ilgili alt başlıklardan grup olarak bireysel sinav yapilırlar.

\section{İşbirliğine Dayalı Öğrenme Yönteminin Faydaları (Yararları-Üstün Yanları)}

İşbirliğine dayalı öğrenme yöntemi öğretim kademelerin tamamında kullanılabilir niteliğe sahip ender yöntemlerden biridir. Bu yöntemin eğitimin üç temel alanı olan bilişsel, duyuşsal ve psikomotor (devinsel) alanlarda yer alan davranışların (amaçların, hedeflerin, kazanımların) kazanılmasında etkili olduğu bilimsel araştırma sonuçlarıyla tespit edilmiştir (Arısoy \& Tarım, 2013; Doğan, Uçar \& Şimşek, 2015; Genç \& Şahin, 2015; Gillies \& Boyle, 2010; Herrmann, 2013; Johnson \& Johnson, 2002; Johnson, Johnson \& Smith, 2007; Johnson, Johnson \& Stanne, 2000; Singh \& Agrawal, 2011; Slavin, 1996; Strohl \& Schneck, 1991; Yeşilyurt, 2019).

İşbirliğine dayalı öğrenme yönteminin yararları maddeler halinde şu şekilde ifade edilebilir (Borich, 2014; Johnson \& Johnson, 1989; Kessler, Price \& Wortman, 1985; Leikin \& Zaslavsky, 1997; Morgan, 2004; Slavin, 1987; Yager \& diğ.,1985):

$\checkmark$ Etkili iletişim becerisi kazanmaya yardımcı olur.

$\checkmark$ Bilginin tam ve derinlemesine öğrenilmesine katkı sağlar.

$\checkmark$ Yaratıcı, yansıtıcı ve eleştirel düşünme becerilerini geliştirir.

$\checkmark$ Problemlerin çözümünde alternatif ve farkı bakış açısı kazandırır.

$\checkmark$ Öğrencilerin derse aktif katılımını, devamını ve akademik başarıyı artırır.

$\checkmark$ Bireysel farklılıkların ortaya çıkarılmasını ve özel eğitme ihtiyaç duyan öğrencilerin tanınmasina firsat sunar.

$\checkmark$ Farklı bakış açısı oluşturarak öğrencilerin kendilerine ait daha net değer ve tutum oluşturmasına yardımcı olur.

$\checkmark$ Keşfedici, araştırıcı, merak uyandırıcı, dikkat çekici, motive edici ve aktif öğrenme ortamı ve süreci oluşturur.

$\checkmark$ Düşünce ve hisleri maskeleyen ilgisiz ve aşırı yüzeyselliklerden sıyrılmayı kolaylaştırır, daha tutarlı ve bütüncül bir kimlik ve benlik hissi oluşturur.

$\checkmark$ Demokratik tutum, değer verme, sevgi, saygı, sosyal etkileşim, güven, paylaşımcılık, dayanışma, sorumluk, liderlik, ortak anlayış, işbirliği ve öğrenme, hoşgörü, biz duygusu, empati, arkadaşlık, dostluk vb. gibi değerlerin kazanılmasına yardımcı olur.

$\checkmark$ Öğrenme sonucu kadar öğrenme sürecine, ölçme ve değerlendirme yöntemlerinde ise geleneksel yöntemlerin yanı sıra tamamlayıcı yöntemlerin de kullanılmasına ve böylece daha güvenilir ve geçerli bir ölçme ve değerlendirme yapılmasına katkı sunar. 
İşbirliğine dayalı öğrenme yönteminin faydaları (olumlu çıktıları) Şekil 2'de yer almaktadır.

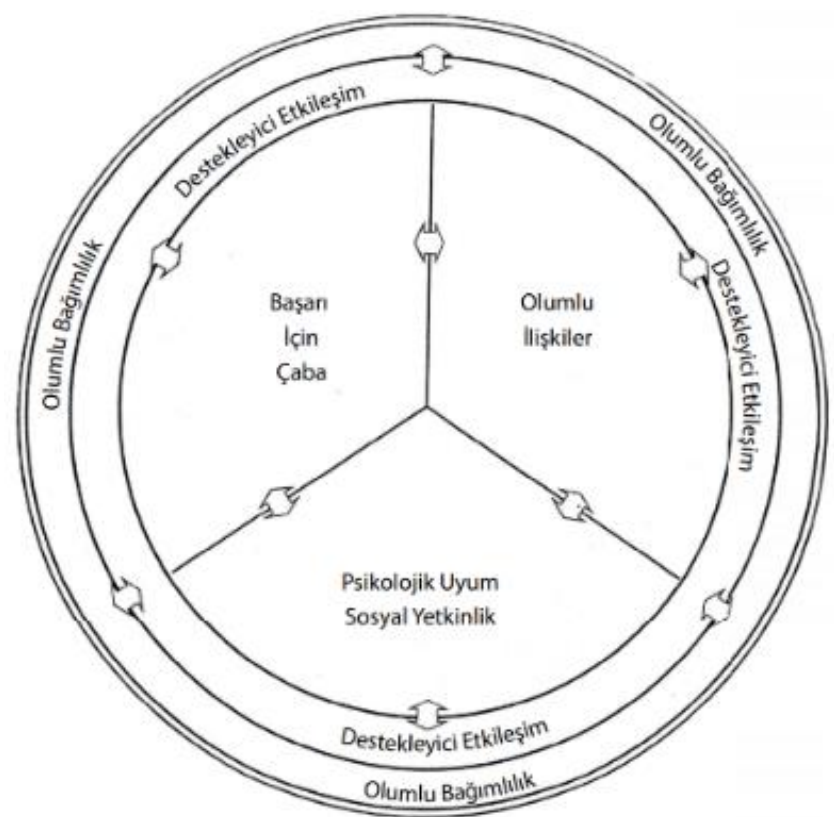

Şekil 2. İşbirlikli öğrenmenin olumlu çıktıları (Kocabaş, Erbil \& Karaaslan, 2016).

\section{İşbirliğine Dayalı Öğrenme Yönteminin Sınırlıkları (Dezavantajları)}

Diğer yöntemlerde olduğu gibi işbirliğine dayalı öğrenme yönteminin de bazı sınırlılıkları ve zorlukları vardır. İşbirlikli öğrenme yöntemin sınırlılıkları şu şekilde sayılabilir (Bratt, 2008; Demirtaş, 2008; Dirlikli, 2015; Felder \& Brent, 2001; Kagan, 1994; Y1ldırım, 2011):

$\checkmark$ Gruplar arasında veya grup içerisinde yıkıcı yarışma ve tartışma yaşanabilir.

$\checkmark$ Görevi yapmayan öğrenciler diğer öğrencilerin öğrenme isteklerini engelleyebilir.

$\checkmark$ Aşırı detaya inme veya çok düşünen yetenekli öğrencilerin öğrenmelerini sağlama bazen zaman kaybına neden olabilir.

$\checkmark$ Üye sayının fazla olduğu gruplarda bazı üyeler "nasılsa diğerleri halleder" düşüncesine kapılarak kişisel çabalarını azaltabilir.

$\checkmark$ Konuyu küçük parçalara bölen grup üyeleri sadece kendi konusu öğrenme sorumluluğu taşıyıp, diğer grup üyelerinin konularını göz ardı edebilir.

$\checkmark$ Özellikle alt öğretim kademelerinde yer alan öğrencilerin oluşturdukları gruplarda başarı düzeyi yüksek olan öğrenciler diğerlerine karşı saygı duymayabilir.

$\checkmark$ Bireysel özellikleri grupta yer alan diğer üyelerden çok yüksek olan bir öğrenci, grup çalışmasını bireysel hız ilkesi açısından eleştirebilir, gereken önemi vermeyebilir ya da kendisinin engellendiğini düşünebilir.

$\checkmark$ Grup içerisindeki düşük yetenekli, pasif, kendine güveni az veya sorumluluk almayan öğrenciler katkıda bulunmadan, öğrenmeden "hazıra konarak" grubun başarısına ortak olabilir, bu durum aktif öğrencilerde "sömürülme" hissi oluşturabilir.

$\checkmark$ Grupta yer alan arkadaşlarına göre daha aktif ve etkin olan, daha fazla iş yaparak daha ön plana çıkan öğrenciler, başta liderlik olmak üzere grubu etki altına alabilir ve grup üzerinde otorite kurabilir, grupta yer alan diğer öğrencileri engelleyebilir ve onları ikinci plana itebilirler. 
Ancak burada dikkat edilmesi gereken nokta iyi yapılandırılmamış, görev ve sorumluluk bilinci iyi oluşturulmamış işbirliğine dayalı öğrenme sürecinde bu ve bunun gibi olumsuzluklar (sınırlıklar, dezavantajlar vb.) yaşandığıdır. İşbirliğine dayalı öğrenme yönteminin amacı, işlevi, önemi, süreci, rolleri, yararları vb. öğrencilere iyi benimsetildiği ve işbirliğine dayalı öğrenme grupları oluşturulduğu zaman bu sınırlıklara oldukça az rastlanılacaktır. Bu durumda bireysel farklılıkları ne ve hangi düzeyse olursa olsun işbirliğine dayalı öğrenme yönteminin grupta yer alan tüm öğrencilerin bilişsel, duyuşsal ve psiko-motor açıdan faydalı ve işlevsel bir yöntem olduğu, sınırlıklarının ise yok denecek kadar az ortaya çıktığı görülmektedir.

\section{Sonuc}

Eğitim sistemlerinin temel amacı, bireylerde istendik yönde davranış değişikliği oluşturmaktadır. İstedik davranış değişikliklerinin oluşmasında "öğrenme" kavramı kilit konumda yer almaktadır. Bu nedenle tarihsel süreçte insanının nasıl öğrendiği merak ve araştırma konusu olmuştur, olmaya da devam edecektir. Günümüzde bu soru bir adım daha ileri taşınmış ve "insan nasıl daha etkili, nitelikli, kalıcı izli, işlevsel vb. öğrenir" sorusuna cevap aranmaya başlanmıştır. Bu sorulara başta eğitim felsefesi ve psikolojisi olmak üzere öğretme-öğretme kuramları, yaklaşımları, modelleri, stilleri, ilkeleri, yöntemleri, teknikleri cevap vermek amacıyla kuram ve uygulamada yerlerini almıştır. İşbirliğine dayalı öğrenme yöntemi de bunlardan biridir. Bugün, gelişmiş veya gelişmekte olan çoğu ülkelerde olduğu gibi ülkemizdeki eğitim sisteminde ve öğretim programlarında da ilerlemecilik eğitim felsefesi, yapılandırmacı ve bilişsel öğrenme kuramları, öğrenci merkezli eğitim, hayat boyu öğrenme, ekip (takım, grup, işbirlikli) çalışması yerini almıştır. İşbirliğine dayalı öğrenme yöntemi ve bu yöntem içerisinde yer alan teknikler teorik ve uygulama açısından bu kavramlara veya ögelere uygun bir öğrenme yöntemidir.

Derleme niteliğinde yürütülen bu çalışmada öncelikle Türkçe ve İngilizce literatürde işbirliğine dayalı öğrenme yönteminin kelime (kavramsal) kökeni ve kullanım şekilleri açıklanmıştır. Öğrenme-öğretim modeli, stratejisi, yaklaşımı, yöntemi kavramlarının kabul gören tanımlarından, literatürde yer alan kullanım (isimlendirme) şekillerinden hareketle ve anlam-içerik olarak hepsini kapsayacak şekilde "işbirliğine dayalı öğrenme yöntemi" şeklinde isimlendirilmiştir. Öte yandan bu yöntemin en temel ögesi olan işbirlikli veya yüksek işbirlikli öğrenme gruplarının geleneksel ve sahte öğrenme gruplarından farklı yönleri ve özelliklerine yer verilmiştir. Ayrıca birden fazla öğrenenin bir araya gelerek oluşturdukları birlikteliğin veya grup çalışmasının işbirliğine dayalı öğrenme olarak nitelendirilebilmesi için;

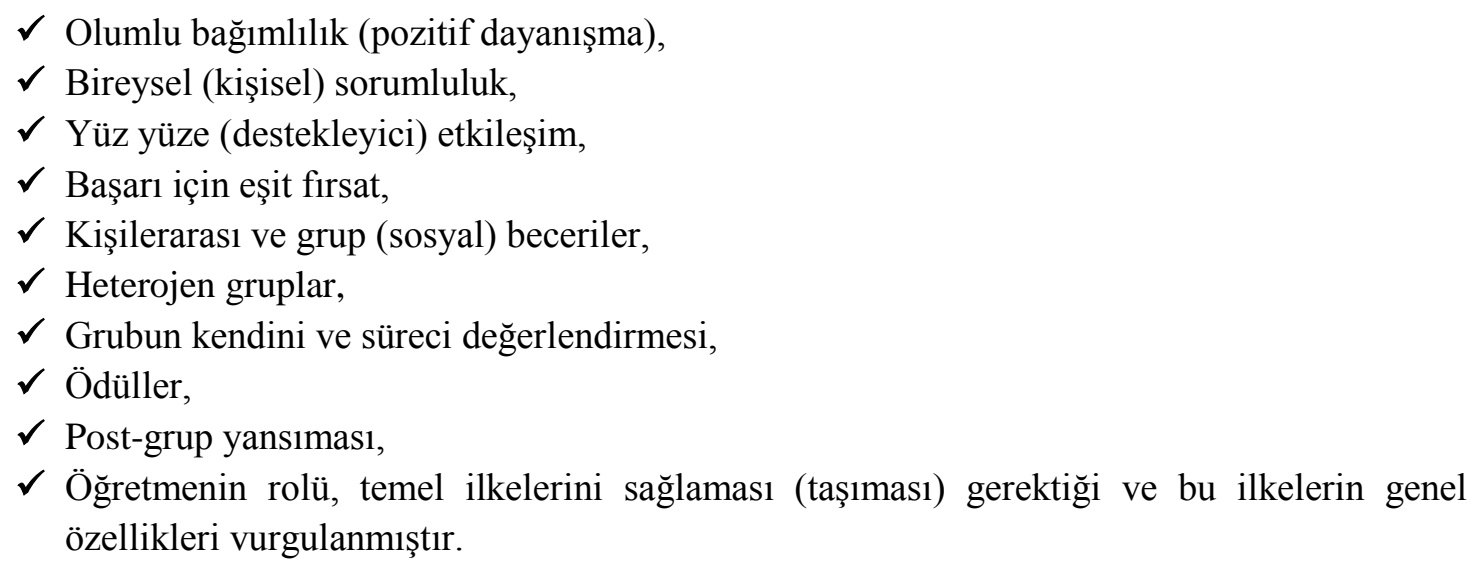

Yapılan literatür taraması sonucunda farklı kaynaklarda işbirliğine dayalı öğrenme yönteminin birçok farklı tekniğinin bulunduğu tespit edilmiştir. Bazı kaynaklarda bir veya birkaç tekniğin detaylı veya çok detaylı verildiği, bazı kaynaklarda tekniklerin genelinin verilmesine rağmen verilen tekniklerin birkaç cümle ile yüzeysel olarak izah edildiği görülmektedir. Ancak ulaşılan kaynaklarda 
işbirliğine dayalı öğrenme tekniklerinin tamamının bir bütünlük içerisinde ve kapsamlı olarak açıklandığı görülmemiştir. Bu çalışmada;

a. Birlikte Öğrenme,

b. Grup Araştırmas1,

c. Takım-Oyun-Turnuva,

d. Birlikte Soralım Birlikte Öğrenelim,

e. Okuma-Yazma-Uygulama,

f. Birleştirilmiş İşbirlikli Okuma ve Kompozisyon,

g. İşbirliği İşbirliği,

h. Öğrenci Takımları - Başarı Bölümleri,

i. Akademik Çelişki /Anlaşmazlık,

j. Karşı1lklı Soralım/ Sorgulama,

k. Takım / Küme Destekli Bireyselleştirme,

l. Birleştirme (Jigsaw),

$\checkmark$ Birleştirme-I (Jigsaw-I),

$\checkmark$ Birleştirme-II Jjigsaw-II),

$\checkmark$ Birleştirme-IIII (Jigsaw-III),

$\checkmark$ Birleştirme-IV (Jigsaw-IV),

$\checkmark$ Konu Birleştirme / Konu Jigsawı,

$\checkmark$ Ters Birleştirme / Ters Jigsaw

olarak isimlendirilen işbirliğine dayalı öğrenme yönteminin teknikleri kapsamlı ve bir bütünlük içerinde ele alınmıştır. Çalışmada son olarak işbirliğine dayalı öğrenme yönteminin faydaları (yararları-üstün yanları) ile sınırlıkları (dezavantajları, zayıf yönleri) detaylı olarak açıklanmıştır.

\section{KAYNAKÇA}

Açıkgöz, K. Ü. (2007) Aktif öğrenme. İzmir: Biliş Yayınları.

Açıkgöz, K. Ü. (1992). İşbirlikli öğrenme: Kuram, araştırma, uygulama. Malatya: Uğurel Matbaası.

Akkuş, A. (2013). Fen ve teknoloji öğretmenlerinin işbirlikli öğrenme modeli hakkında bilgilendirilmesi, bu modeli sinıfta uygulamaları ve elde edilen sonuçların değerlendirilmesi: Muş il örneği. Doktora tezi: Atatürk Üniversitesi.

Aksoy, G. \& Doymuş, K. (2011). Fen ve teknoloji dersi uygulamalarında işbirlikli okuma-yazmauygulama tekniğinin etkisi. Gazi Eğitim Fakültesi Dergisi, 31(2), 381-397.

Aksoy, G. (2011). Öğrencilerin fen ve teknoloji dersindeki deneyleri anlamalarına okuma-yazmauygulama ve birlikte ögrenme yöntemlerinin etkileri. Doktora tezi: Atatürk Üniversitesi.

Arısoy, B. \& Tarım, K. (2013). İşbirlikli öğrenme yönteminin öğrencilerin akademik başarı, kalıcılık ve sosyal beceri düzeylerine etkisi. H.Ü. Eğitim Fakültesi Dergisi, 28(3), 1-14.

Aronson, E. (1978). The Jigsaw classroom. Beverly Hills, CA: Sage Publication.

Aydal, M. (2017). İşbirlikli öğrenmeye dayalı öğrenme yaklaşımının görsel sanatlar dersindeki erişiye, tutuma ve ögrenilenlerin kalıcılığına etkisi. Doktora tezi: N. Erbakan Üniversitesi.

Baykara, K. (2000). İşbirliğine dayalı öğrenme teknikleri ve denetim odakları üzerine bir çalışma. Hacettepe Üniversitesi Ĕ̈itim Fakültesi Dergisi, (18), 201-210. 
Bilen, M. (2006). Plandan uygulamaya öğretim. Ankara: Anı Yayıncılık.

Bilgin, İ. (2006). Fen ve teknoloji öğretimi (Ed: M. Bahar), İşbirlikli öğrenme (ss.137-158). Ankara: Pegem Akademi Yayıncılık.

Bilgin, İ., Aktaş, İ. \& Çetin, A. (2014). Öğrenci takımları başarı bölümleri tekniğinin ilköğretim öğrencilerinin zihinsel yapılarına etkisi, İlköğretim Online, 13(4), 1352-1372.

Borich, G. D. (2014). Effective teaching methods (Etkili öğretim yöntemleri, Çev. Editörü: M. B. Acat), İşbirlikli öğrenme ve işbirliği süreci (ss.352-377; Çev: H. Sucuoğlu). Ankara: Nobel Akademik Yayıncılık.

Bölükbaş, F. (2014). Jigsaw-IV tekniğinin yabancı öğrencilerin Türkçedeki temel zamanlanı öğrenmeleri üzerindeki etkisi. Uluslararası Türkçe Edebiyat Kültür Eğitim Dergisi, 3(3), 196209.

Bratt, C. (2008). The Jigsaw classroom under test: No effect on intergroup relations evident. Journal of Community \& Applied Social Psychology, 18(5), 403-419.

Çavdar, O. (2016). İşbirlikli öğrenme yönteminin iyi bir eğitim ortamı için yedi ilke ve modellerle birlikte kullanılmasının 7. sınıf maddenin yapısı ve özellikleri ünitesinin anlaşılmasına etkisi. Doktora tezi: Atatürk Üniversitesi.

Çelik, E. (2017). Cebir öğrenme alanında probleme dayalı işbirlikli öğrenmenin akademik başarıya etkisinin incelenmesi. Doktora tezi: Atatürk Üniversitesi.

De Vries, D. L. \& Slavin, R. E. (1978). Teams-games-tournaments (TGT): Review of ten classroom experiments. Journal of Research and Development in Education, 12(1), 28-38.

Demirel, Ö. (2007). Öğretim ilke ve yöntemleri, ögrretmen sanatı. Ankara: Pegem A Yayıncıllk.

Demirtaş, F. (2008). İşbirlikli ögrenmede birleştirme I tekniğinin ilköğretim beşinci sinıf ögrencilerinin fen ve teknoloji dersine ilişkin tutumların etkisi. Yüksek lisans tezi: A.İ. Baysal Üniversitesi.

Dirlikli, M. (2015). İşbirlikli öğrenme yöntemlerinin çemberin analitik incelenmesi konusunda akademik başarıya, kalıcılığa etkisi ve sınıf içi yansımaları. Doktora tezi: Atatürk Üniversitesi.

Doğan, A., Uçar, S. \& Şimşek, Ü. (2015). Jigsaw tekniğinin 6.sınıf fen ve teknoloji dersi “yer kabuğu nelerden oluşur?" ünitesinin öğretiminde öğrenci başarısına etkisi. Mustafa Kemal Üniversitesi Sosyal Bilimler Enstitüsü Dergisi, 12(32), 416-432.

Doğru, M. \& Ünlü, S. (2012). Jigsaw IV tekniği kullanımının fen öğretiminde öğrencilerin motivasyon, fen kaygısı ve akademik başarılarına etkisi. Mediterranean Journal of Humanities, II(2), 57-66.

Doymuş, K. (2007). Effects of a cooperative learning strategy on teaching and learning phases of matter and one-component phase diagrams. Journal of Chemical Education, 84(11), 18571860.

Efe, R., Havedanlı, M., Ketani, Ş., Çakmak, Ö. \& Efe, H. A. (2008). İşbirlikli ögrrenme teori ve uygulama. Ankara: Eflatun Basım Dağıtım Yayıncılık.

Ekici, N. (2007). Eğitimde yeni yönelimler (Ed. Ö. Demirel), İşbirliğine dayalı öğrenme (ss. 93-109). Ankara: Pegem A Yayıncılık.

Felder, R. M. \& Brent, R. (2001). Effective strategies for cooperative learning. Journal of Cooperation \& Collaboration in College Teaching, 10(2), 69-75. 
Gelici, Ö. \& Bilgin, İ. (2011). İşbirlikli öğrenme tekniklerinin tanıtımı ve öğrenci görüşlerinin incelenmesi. Adyyaman Üniversitesi Fen Bilimleri Dergisi, 1(1), 40-70.

Genç, M. \& Şahin, F. (2015). İşbirlikli öğrenmenin başarıya ve tutuma etkisi. Necatibey Eğitim Fakültesi Elektronik Fen ve Matematik Eğitimi Dergisi, 9(1), 375-396.

Gillies, R. M. \& Boyle, M. (2010). Teachers' reflections on cooperative learning: Issues of implementation. Teaching and Teacher Education, 26(2010), 933-940.

Gömleksiz, M. (1993). Kubaşık öğrenme yöntemi ile geleneksel yöntemin demokratik tutumlar ve erişiye etkisi. Doktora tezi: Çukurova Üniversitesi.

Güneş, F. (2014). Öğretim ilke ve yöntemleri (Ed: F. Güneş), Öğretim stratejileri (ss. 59-92). Ankara: Pegem Akademi.

Hedeen, T. (2003). The reverse Jigsaw: A process of cooperative learning and discussion. Teaching Sociology, 31(3), 325-332.

Herrmann, K. J. (2013). The impact of cooperative learning on student engagement: Results from an intervention. Active Learning in Higher Education, 14(3) 175-187.

Holliday, D. C. (2000). The development of Jigsaw IV in a secondary social studies classroom. https://files.eric.ed.gov/fulltext/ED447045.pdf, Erişim Tarihi:10.06.2019.

İflazoğlu, A. (1999). Küme destekli bireyselleştirme tekniğinin temel eğitim beşinci sını ögrencilerinin matematik başarısı ve matematiğe ilişkin tutumları üzerindeki etkisi. Yüksek lisans tezi: Çukurova Üniversitesi.

Johnson, D. W. \& Johnson, R. T. (1989). Cooperation and competition: Theory and research. Edina, $\mathrm{MN}$ : Interaction Book Company.

Johnson, D. W. \& Johnson, R. T. (2002). Learning together and alone: Overview and meta-analysis. Asia Pacific Journal of Education, 22(1), 95-105.

Johnson, D. W. (1997). Academic controversy. Higher Education Report, 25(3), https://files.eric.ed.gov/fulltext/ED409829.pdf, Erişim Tarihi: 13.06.2019.

Johnson, D. W., Johnson, R. T. \& Smith, K. A. (2007). The state of cooperative learning in postsecondary and professional settings. Educational Psychology Review, 19(1), 15-29.

Johnson, D. W., Johnson, R. T. \& Stanne, M. B. (2000). Cooperative learning methods: A metaanalysis.https://www.researchgate.net/publication/220040324_Cooperative_learning_methods _A_meta-analysis, Erişim tarihi: 12.06.2019.

Kagan, S. (1994). Cooperative learning. San Clemente, CA: Kagan Publishing.

Kaya, M. F. (2015). Öğretim ilke ve yöntemleri (Ed: S. Güven \& M. A. Özerbaş), Öğrenme-öğretme stratejileri ve modelleri (ss. 179-236). Ankara: Pegem Akademi

Kessler, R. C., Price, R. H. \& Wortman, C. B. (1985). Social factors in psychopathology: Stress, social support and coping processes. Annual Review of Psychology, (36), 351-372.

Kılınç, A. (2014). İsbirlikli öğrenme yönteminin (Jigsaw tekniği)) asitler ve bazlar konusunda öğrenci başarısına etkisi ve ögrrenci görüşleri. Yüksek lisans tezi: Gazi Üniversitesi.

Kocabaş, A., Erbil, D. G. \& Karaaslan, T. (2016). İşbirlikli öğrenme el kitabı. Ankara: Pegem Akademi. 
Koç, Y. (2014). Fen ve teknoloji öğretmenlerinin işbirlikli öğrenme modeli hakkında bilgilendirilmesi, bu modeli sınıfta uygulamaları ve elde edilen sonuçların değerlendirilmesi: A Doktora tezi: Atatürk Üniversitesi.

Köseoğlu, P. (2010). Biyoloji eğitiminde birleştirme tekniği temelli öğretimin akademik başarı, özyeterlik ve tutuma etkisi, H.Ü. Ë̆itim Fakültesi Dergisi, (39), 244-254.

Leikin, R. \& Zaslavsky, O. (1997). Facilitating student interactions in mathematics in a cooperative learning setting. Journal of Research in Mathematics Education, 28(3), 331-359.

Maden, S. (2011a). Takım oyun turnuva tekniğinin yazım kuralları ve işaretleri eğitiminde kullanımı. e-International Journal of Educational Research, 2(3), 52-67.

Maden, S. (2011b). Jigsaw I tekniğinin yazılı anlatım becerisi akademik başarısına etkisi. Kuram ve Uygulamada Eğitim Bilimleri, 11(2), 901-917.

Morgan, B. M. (2004). Cooperative learning in higher education: Hispanic and nonhispanic undergraduates' reflections on group grades. Journal of Latinos and Education, 3(1), 39-52.

Ocak, G. (2011). Öğretim ilke ve yöntemleri, (Editör: G. Ocak), Yöntem ve teknikler, (ss. 237-336). Ankara: Pegem A Yayıncilik.

Özer, M. A. (2005). Etkin Öğrenmede yeni arayışlar: İşbirliğine dayalı öğrenme ve buluş yoluyla öğrenme. Bilig, (35), 105-131.

Özyurt, D. A (2013). Fen ve teknoloji dersinin uygulamalarında işbirlikli öğrenme modelinin ögrencilerin akademik başarısına etkisi. Yüksek lisans tezi: Atatürk Üniversitesi.

Senemoğlu, N. (2005). Gelişim, öğrenme ve ögrretim: Kuramdan uygulamaya. Ankara: Gazi Kitapevi.

Sharan, S. \& Hertz-Lazarowits, R. (1980). A group investigation method of cooperative learning in the classroom (Ed: Sharan, S., Hare, P., Webb, C. \& Hertz-Lazarowits, R.), Cooperative learning in education (pp.14-16). Provo, UT: Birgham Young University Pres.

Singh, Y. P. \& Agrawal, A. (2011). Introduction to co-operative learning. Indian Streams Research Journal, 1(2), 1-9.

Slavin, R. E. (1984). Team assisted individualization: Cooperative learning and individualized instruction in the mainstreamed classroom. Remedial and Special Education, 5(6), 33-42.

Slavin, R. E. (1987). Cooperative learning: Can students help students learn. Washington: National Education Association.

Slavin, R. E. (1995). Cooperative learning: Theory, research, and practice. Boston: Allyn \& Bacon.

Slavin, R. E. (1996). Research for the future. Research on cooperative learning and achievement: What we know, what we need to know. Contemporary Educational Psychology, 21(1), 43-69.

Stahl, R. (1994). Cooperative learning in social studies: A handbook for teachers. Menlo Park, CA: Addison-Wesley.

Sönmez, V. (2008). Öğretim ilke ve yöntemleri. Ankara: Anı Yayıncılık.

Stevens, R. J., Madden, N. A., Slavin, R. E. \& Farnish, A. M. (1987). Cooperative integrated reading and composition: Two field experiments. Reading Research Quarterly, 22(4), 433-454.

Strohl, M. \& Schneck, S. (1991). Colonial America: Cooperative learning activities. New York: Scholastic Professional Books.

Sünbül, A. M. (2011). Öğretim ilke ve yöntemleri. Konya: Eğitim Yayınc1l1k. 
Şimşek, Ü. (2007). Çözeltiler ve kimyasal denge konularında uygulanan Jigsaw ve birlikte öğrenme tekniklerinin ögrencilerin maddenin tanecikli yapıda ögrrenmeleri ve akademik başarıları üzerine etkisi. Doktora tezi: Atatürk Üniversitesi.

Tan, Ş. (2006). Öğretimi planlama ve değerlendirme. Ankara: Pegem A Yayıncılık.

Taşpınar, M. \& Atıcı, B. (2002). Öğretim model, strateji, yöntem ve becerileri/teknikleri: kavramsal boyut. Ë̆itim Araştırmaları, 2(8), 207-215.

Taşpınar, M. (2012). Kuramdan uygulamaya öğretim yöntemleri. Ankara: Elhan Kitap Yayın Dağıtım.

Tok, Ş. (2012). Öğretim ilke ve yöntemleri (Ed: A. Doğanay), Etkili ögrretim için yöntem ve teknikler (ss. 161-237). Ankara: Pegem Akademi.

Türkmen, H. \& Atasayar Yamık, G. (2015). Jigsaw-II tekniğinin omurgalı hayvanlar konusunda öğrenci başarısına etkisi. The Journal of Academic Social Science Studies, 36(II), 33-46.

Varışoğlu, B. (2016). İşbirlikli okuma ve yazma etkinliklerinin Türkçe öğrenen yabanı öğrencilerin dil kaygilarına etkisi. Elektronik Sosyal Bilimler Dergisi, 15(59), 1108-1119.

Yager, S., Johnson, R., Johnson, D. W. \& Snider, B. (1985). The effect of cooperative and individualistic learning experiences on positive and negative cross-handicap relations contemporary. Educational Psychology, 10(2), 127-138.

Yeşilyurt, E. (2009). İşbirliğine dayalı öğrenmenin öğrenci davranışları üzerindeki etkisine ilişkin öğrenci görüssleri. Firat Üniversitesi Sosyal Bilimler Dergisi, 19(2), 161-178.

Yeşilyurt, E. (2010). Öğretmen adayları niteliklerinin işbirliğine dayalı öğrenme yöntemine uygunluğunun değerlendirilmesi. Ziya Gökalp Eğitim Fakültesi Dergisi, (14), 25-37.

Yeşilyurt, E. (2019). Değerler eğitimine uygunluğu açısından öğretim yöntem ve tekniklerinin incelenmesi: Bir derleme çalışması. Ekev Akademi Dergisi, 23(77), 121-146.

Yıldırım, B. (2011). İlköğretim 8 sınıf fen bilgisi dersinde kalıtım ünitesinin işlenmesinde işbirlikli ögrenme yönteminin ögrrenci başarısına ve kalıcılı̆̆ına etkisi. Yüksek lisans tezi: Gazi Üniversitesi.

Yıldız, E., Çalıklar, Ş., Ilgaz, S. \& Şimşek, U. (2017). Jigsaw tekniği ve birlikte soralım birlikte öğrenelim yönteminin öğretmen adaylarının iyi bir eğitim için yedi ilke hakkındaki görüşleri üzerine etkisi. Turkish Studies, 12(14), 573-588.

Yıldız, V. (1999). İşbirlikli öğrenme ile geleneksel öğrenme grupları arasındaki farklar. Hacettepe Üniversitesi Eğitim Fakültesi Dergisi, (16-17), 155-163.

Yılmaz Güngör, Z. (2011). Birleştirme-II tekniğinin Fransızca okuma dersinde öğrenilen sözcükleri hatırda tutmaya etkisi. Dokuz Eylül Üniversitesi Sosyal Bilimler Enstitüsü Dergisi, 13(4), 7584. 